$10-1-2010$

\title{
Rhetorical Federalism: The Value of State-Based Dissent to Federal Health Reform
}

\author{
Elizabeth Weeks Leonard \\ University of Georgia School of Law, weeksleo@uga.edu
}

p bepress $S$ TSR

\section{Repository Citation}

Elizabeth Weeks Leonard, Rhetorical Federalism: The Value of State-Based Dissent to Federal Health Reform (2010),

Available at: https://digitalcommons.law.uga.edu/fac_artchop/769

This Article is brought to you for free and open access by the Faculty Scholarship at Digital Commons @ University of Georgia School of Law. It has been accepted for inclusion in Scholarly Works by an authorized administrator of Digital Commons @ University of Georgia School of Law. Please share how you have benefited from this access For more information, please contact tstriepe@uga.edu. 


\title{
RHETORICAL FEDERALISM: THE VALUE OF STATE-BASED DISSENT TO FEDERAL HEALTH REFORM
}

\author{
Elizabeth Weeks Leonard*
}

This Article makes the affirmative case for the widespread trend of state resistance to the recently enacted, comprehensive federal health reform law, the Patient Protection and Affordable Care Act of 2010 ("ACA"). A significant number of states have engaged in various forms of objection to the new federal laws, including filing lawsuits against the federal government, enacting laws providing that $A C A$ will not apply to residents of the state, and refusing to cooperate with implementing the new laws. This Article identifies reasons why those actions should not be disregarded simply as Tea Party antics or election-year gamesmanship but instead should be considered valuable to health care policymaking and federal-state relations. In making the case for rhetorical federalism, this Article examines and expands previously articulated theories, including uncooperative federalism and opportunistic federalism. Key provisions of ACA implicating states are examined under the operative theories.

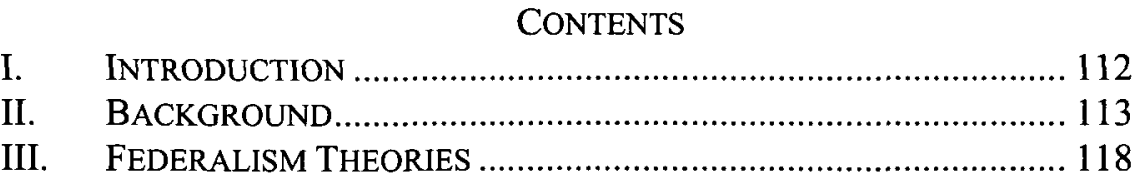

* Visiting Professor of Law, University of Georgia; Professor of Law, University of Kansas. I am grateful to Mike Wells, Mark Hall, Tim Jost, Abby Moncrieff, Abbe Gluck, Tara Leigh Grove, Nicole Huberfeld, Rick Levy, and Chris Drahozal; and participants at Health Law Professors Conference at the University of Texas School of Law, Midwestern Law \& Economics Association Annual Meeting at University of Colorado School of Law, Central States Law School Association Annual Meeting at University of North Dakota School of Law, and faculty workshops at Loyola University Chicago School of Law, University of Georgia School of Law, University of the Pacific McGeorge School of Law, and University of Kansas International Seminar for Faculty and School of Law for comments and suggestions to improve this draft. I received excellent research assistance from Brandon Smith, Hannah Sandal, and Brian Henson. 
A. Uncooperative Federalism................................................ 119

B. Opportunistic Federalism .................................................. 125

IV. Role OF States IN FEDERAL HEALTh ReForm....................... 132

A. Medicaid Expansion ........................................................ 134

B. High-Risk Pools ............................................................. 140

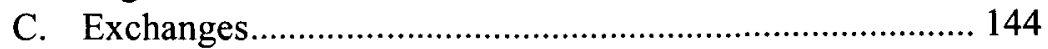

D. Insurance Market Regulations ........................................... 150

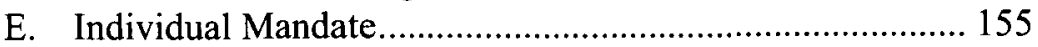

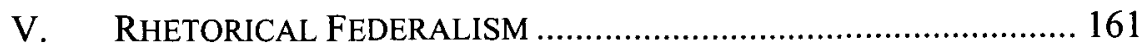

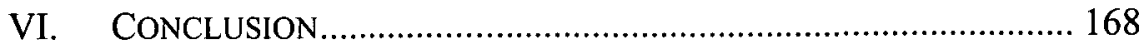

\section{INTRODUCTION}

This Article makes the affirmative case for the health reform nullification movement. In so doing, the discussion develops a conceptual theory of "rhetorical federalism" to encompass the range of state reactions, and notable non-reactions, to the recently enacted Patient Protection and Affordable Care Act ("ACA"). ${ }^{1}$ By rhetorical federalism, this Article means the highly public, highly vocal invocation of statesrights arguments to frame objections to comprehensive, sea-changing federal policies. The theory is normative inasmuch as it finds value in state-based resistance although not condoning all of the strategies employed.

Values of rhetorical federalism include bringing transparency to the task of implementing comprehensive laws, educating the electorate by distilling the law to discrete issues, giving voice to minority views, depoliticizing highly charged issues, codifying dissent, and highlighting the increased role of government in health care delivery. ${ }^{2}$ Rhetorical federalism is inevitably, and I suggest appropriately, an amalgam of slogans, some sincere and some opportunistic. Cooperative federalism, dual sovereignty, new federalism, and traditional "Our Federalism" themes all find voice in the current discussion. Even if some of the rhetoric is empty, it has the potential to sharpen the debate and build appreciation for the challenges of implementing major new policies, while renewing deliberation about the appropriate role of states in federal policymaking and government in individuals' lives.

State-centered dissent, such as refusing to implement new federal legislation, challenging the constitutionality of federal laws, resisting federal mandates, ignoring federal precedent, and even threatening to

1. Patient Protection and Affordable Care Act, Pub. L. No. 111-148, 124 Stat. 119 (2010), amended by Health Care and Reconciliation Act of 2010, Pub. L. No. $111-152,124$ Stat. 1029.

2. See infra Part V. 
secede from the Union, would seem to hinder productive functioning within the federal system. In response to ACA, states mounted resistance through all of those means. In the view of many, state resistance is legally null, at best, and destructive, at worst. This Article offers a counter-view, suggesting that the rhetoric of federalism, even when invoked inconsistently and opportunistically, may have a salutary effect on both health care decisionmaking and federal-state relations.

The point here is not to argue the merits of particular provisions of ACA or various state lawsuits, amendments, and resolutions. Rather, this Article considers the potential benefits deriving from the apparently distracting and obstructive health reform nullification trend. Part II describes the current landscape of state resistance to ACA. Part III considers plausible federalism theories to rationalize the state nullification movement. Part IV outlines key provisions of ACA that implicate states or have been targets of state objections and tests them against the operative theories. Part V concludes by suggesting several possible benefits of rhetorical federalism.

\section{BACKGROUND}

I was among the health reform pessimists: Throughout the protracted congressional debates and up until March 23, 2010, when President Obama signed ACA into law, ${ }^{3}$ I predicted that incremental changes, if any, would be enacted. Earlier versions of this Article theorized that state constitutional amendments and legislative resolutions purporting to nullify various provisions of the anticipated reforms would provide a jumping off point for the inevitable next attempt at comprehensive health reform. At least we would know going forward that certain approaches-national health plan, public option, individual health insurance mandate-would be political non-starters and could get down to the business of hashing out the remaining viable options.

To my surprise, the bill passed. And state objections continued, escalated, and morphed. During and after congressional debates, at least forty states considered state constitutional amendments or legislative resolutions purporting to nullify various provisions of the proposed law. ${ }^{4}$ Seven states-Virginia, Idaho, Utah, Georgia, Louisiana, Missouri, and Arizona-enacted resolutions establishing that citizens of their

3. Patient Protection and Affordable Care Act, 124 Stat. at 1024.

4. See Richard Cauchi, State Legislation Challenging Certain Health Reforms, 2010, NAT'L CONF. ST. LEGISLATURES, http://www.ncsl.org/default.aspx?tabid=18906 (last updated Jan. 10, 2011) (summarizing thirty states' proposed constitutional amendments and over sixteen states' proposed legislation). 
respective states would not be required to comply with the new federal mandate that all individuals obtain health insurance. ${ }^{5}$ Missouri voters approved a ballot measure prohibiting the federal or state government from mandating that Missouri residents obtain health insurance or from penalizing residents for directly paying their medical bills. ${ }^{6}$ Arizona and Oklahoma held constitutional ballot questions in 2010 on amendments purporting to nullify the individual insurance mandate. ${ }^{7}$ In addition to state laws, Idaho's House and Senate passed a resolution calling for a Twenty-eighth Amendment to the U.S. Constitution providing that "Congress shall make no law requiring citizens of the United States to enroll in, participate in or secure health care insurance or to penalize any citizen who declines to purchase . . health care insurance." 8

Many of the state nullification resolutions and amendments are phrased in terms of individual rights, providing that citizens of the respective states will not be required to participate in any particular health plan. ${ }^{9}$ Others recognize individuals' rights to purchase health care directly from health care providers, rather than through health insurance plans. ${ }^{10}$ Some earlier state resolutions and amendments objected to universal health care, a national health plan, or a public option, ${ }^{11}$ vestiges of President Clinton's 1993 failed health reform effort, which were never seriously considered in the current debates. Other resolutions focus on the states' role in health reform implementation, prohibiting state regulators and law enforcement officials from being required to implement federal programs, ${ }^{12}$ or from punishing individuals, employers, or providers who refuse to comply with federal mandates. ${ }^{13}$

5. See id.

6. See Mark Trumbull, Missouri Voters Stage Revolt Against Obama Health-Care Reform, CHRISTIAN SCI. MONITOR (Aug. 4, 2010), http://www.csmonitor.com/USA/Politics/2010/0804/ Missouri-voters-stage-revolt-against-Obama-health-care-reform (reporting that seventy percent of voters approved the measure).

7. See Cauchi, supra note 4 (reporting that $55.4 \%$ of Arizonans and $64.73 \%$ of Oklahomans voted to pass the proposed legislation). Florida's proposed constitutional amendment was scheduled for vote on November 2, 2010, but was stricken from the ballot by the state supreme court as misleading or unclear. See Bill Kaczor, Florida Justices Nix Health Care Amendment, BLOOMBERG BUS. WK. (Sept. 1, 2010, 8:10AM ET), http://www.businessweek.com/ap/financialnews/D9HV 45JO0.htm.

8. Cauchi, supra note 4 .

9. See id. at tbl.1 (describing resolutions and amendments in several states, such as Alabama, Florida, Georgia, Idaho, Illinois, Indiana, Kansas, Kentucky, Minnesota, and South Carolina).

10. See id. (listing Alaska, Arizona, Arkansas, Georgia, Iowa, Kansas, Kentucky, Maryland, and Michigan among these states).

11. See id. (describing such resolutions in the states of Alaska, Indiana, and Iowa).

12. See id. (listing Kentucky, New Hampshire, Pennsylvania, and South Carolina among these states).

13. See id. (listing proposed legislation that would preclude penalty in Louisiana, Maryland, Virginia, and Wyoming). 
Some proposals codify states' rights to opt-out of federal health reforms. ${ }^{14}$ One California senator proposed a sweeping amendment prohibiting state enforcement of a host of provisions, including the individual mandate, employer mandate, public option, guaranteed issue, and universal health care. ${ }^{15}$ Five states considered legislation objecting to the fiscal impact of ACA, in particular, Medicaid expansion. ${ }^{16}$ In addition to specific health reform nullification proposals, lawmakers in forty-three states introduced general Tenth Amendment "reinvigoration" amendments or resolutions, affirming states' constitutionally reserved powers. $^{17}$

Within hours of the President's signing ACA into law, thirteen states' attorneys general filed federal lawsuits challenging the constitutionality of the law. ${ }^{18} \mathrm{Six}$ additional states joined the lawsuits in the subsequent weeks. ${ }^{19}$ By June 2010, twenty states had joined the suits. $^{20}$ By January 2011, more than half the states entered lawsuits challenging $\mathrm{ACA}^{21}$ The first suit, filed by Virginia's Attorney General, ${ }^{22}$ rests on Virginia's recently enacted statute providing that no resident of the state "shall be required to obtain or maintain a policy of individual insurance coverage." ${ }^{23}$ The lawsuit asserts standing based on the state's sovereign interest in enforcing a validly enacted state law that directly conflicts with the new federal law. ${ }^{24}$ On the merits, the suit

14. See id. (noting states that have proposed opt-out programs, including Arizona, Colorado, Delaware, Oklahoma, and Utah).

15. See id.

16. See id. (listing Arizona, Illinois, Iowa, Michigan, and New Hampshire as "States Opposing Health Reform Financing and Unfunded Mandates").

17. See 10th Amendment Resolutions, TENTH AMENDMENT CENTER, http://www.tenthamendmentcenter.com/nullification/10th-amendment-resolutions/ (last visited Jan. 31, 2011).

18. See Complaint at 1-2, 4, Florida ex rel. McCollum v. U.S. Dep't of Health \& Human Servs., No. 3:10-cv-91 (N.D. Fla. Mar. 23, 2010) [hereinafter Florida Complaint], available at http://myfloridalegal.com/webfiles.nsf/WF/MRAY-83TKWB/\$file/HealthCareReformLawsuit.pdf; see also Complaint for Declaratory and Injunctive Relief at 6 , Virginia ex rel. Cuccinelli v. Sebelius, No. 3:10-cv-188 (E.D. Va. Mar. 23, 2010) [hereinafter Virginia Complaint], available at http://www.oag.state.va.us/PRESS_RELEASES/Cuccinelli/Comm $\% 20 \mathrm{v} . \% 20$ Sebelius $\% 20-\% 20$ Complaint $\% 20$ filed $\% 20$ with $\% 20$ Court $\% 20 \_323 \_10$.pdf (an action by the state of Virginia against Kathleen Sebelius, Secretary of the U.S. Department of Health and Human Services).

19. See Melissa Nelson, Judge to Speed Federal Health Care Challenge, PRESs \& DAKOTAN (Apr. 15, 2010, 12:08 AM CDT), http://www.yankton.net/articles/2010/04/15/news/doc4bc694aa9d 37a140784199.txt.

20. See Cauchi, supra note 4, at tbl.2.

21. See Kate Pickert, More Than Half of All States Now Suing Over Health Reform, TIME, Jan. 20, 2011, available at http://swampland.blogs.time.com/2011/01/20/more-than-half-of-allstates-now-suing-over-health-reform/.

22. See Virginia Complaint, supra note 18 , at 1 .

23. Id. at 2 (quoting VA. CoDE ANN. § 38.2-3430.1:1 (Supp. 2010)).

24. See id. 
alleges that the individual insurance mandate exceeds Congress' power to regulate interstate commerce. ${ }^{25} \mathrm{~A}$ second suit, initially filed by Florida and nineteen additional states, ${ }^{26}$ also challenges the individual mandate, as well as Medicaid expansion and health insurance Exchanges, as encroachments on states' Tenth Amendment reserved powers. ${ }^{27}$ Despite commentators' suggestions that the lawsuits are "losers," 28 both the Virginia and Florida cases have survived the government's motions to dismiss. ${ }^{29}$ On January 31, 2011, District Judge Roger Vinson granted the States' motion for summary judgment in the Florida lawsuit, holding the individual mandate unconstitutional and inseverable, effectively invalidating the entire ACA, although not enjoining ongoing implementation or enforcement. ${ }^{30}$

In addition to legislative and judicial fronts, states have registered objection to ACA by refusing to assist the federal government in implementing several provisions that specifically call for state cooperation. Georgia's insurance commissioner and gubernatorial candidate took the lead in informing Kathleen Sebelius, U.S. Secretary of Health and Human Services, that he would not comply with the Secretary's request to create a state high-risk insurance pool. ${ }^{31}$

25. See id. at 5-6.

26. See Florida Complaint, supra note 18, at 1-2; see also Nelson, supra note 19 (noting that six additional states ultimately joined the Florida suit).

27. See Florida Complaint, supra note 18, at 4-6.

28. See, e.g., Jack M. Balkin, The Constitutionality of the Individual Mandate for Health Insurance, 362 NEw ENG. J. MED. 482, 483 (2010); Mark A. Hall, The Constitutionality of Mandates to Purchase Health Insurance, J.L. MED. \& ETHICS, Fall 2009, at 40, 42, 48; Sara Rosenbaum, $A$ "Customary and Necessary" Program-Medicaid and Health Reform, 362 NEW ENG. J. MED. 1952, 1954 (2010) ("The states' legal claims border on the frivolous ...."); Aziz Huq, Bad Law, Smart Politics in Constitutional Challenges to Healthcare Reform, NATION (Apr. 15, 2010), http://www.thenation.com/article/bad-law-smart-politics-constitutional-challengeshealthcare-reform ("Even a cursory glance at the Florida and Virginia complaints reveals that neither lawsuit really turns on a plausible reading of the law today."); Keith L. Martin, Law Professor: Health Reform Lawsuits in Va. Other States 'A Loser,' INS. \& FIN. ADVISOR (May 18, 2010), http://ifawebnews.com/2010/05/18/law-professor-health-reform-lawsuits-in-va-other-statesa-loser/. But see Randy E. Bamett, Can the Constitution Stop Health-Care Reform?, WASH. POST, Mar. 21, 2010, at B2 (noting that the health care reform may be outside the bounds of Congress' power); David B. Rivkin \& Lee A. Casey, Illegal Health Reform, WASH. POST, Aug. 22, 2009, at Al5 (arguing that Congress cannot impose a federal mandate that requires Americans to purchase health insurance).

29. See Florida ex rel. McCollum v. U.S. Dep't of Health \& Human Servs., 716 F. Supp. 2d 1120, 1164-65 (N.D. Fla. 2010) (denying defendant's motion to dismiss); Virginia ex rel. Cuccinelli v. Sebelius, 702 F. Supp. 2d 598, 607-08, 615 (E.D. Va. 2010) (same).

30. See Florida ex rel. Bondi v. U.S. Dep't of Health \& Human Servs., No. 3:10-cv-91RV/EMT, 2011 U.S. Dist. LEXIS 8822 (N.D. Fla. Jan. 31, 2011) (granting plaintiffs' motion for summary judgment) [hereinafter Florida Summary Judgment]. A copy of this opinion is available at http://aca-litigation.wikispaces.com/file/view/District+Court+final+opinion.pdf.

31. See Robbie Brown, Georgia Insurance Commissioner Balks at Request on New Health 
Subsequently, at least nineteen more states, with both Republican and Democratic governors, similarly declined federal grants to establish high-risk pools, leaving the job to the federal government. ${ }^{32}$ If states are concerned about erosion of their reserved powers, it is difficult to explain their apparent preference for federal intrusion on traditional state authority over the business of insurance. ${ }^{33}$

It is easy to dismiss those efforts as nothing more than political theater, election-year gamesmanship, and Tea Party antics. The states' lawsuits, asserting that the individual mandate is an unprecedented, unconstitutional extension of federal commerce power, were generally dismissed as meritless. ${ }^{34}$ Resolutions suggesting that federal law would not apply within particular states' borders are null as a matter of the Constitution's Supremacy Clause. ${ }^{35}$ The likelihood of a federal constitutional amendment overturning ACA is exceedingly unlikely. ${ }^{36}$ There is a long history of state nullification efforts in the nation's history, ${ }^{37}$ including recent, similar efforts by states and localities opposing the post-9/11 Uniting and Strengthening America by Providing Appropriate Tools Required to Intercept and Obstruct Terrorism Act (the "PATRIOT Act"). ${ }^{38}$ But notions of state-level armed resistance, ${ }^{39}$ a

Law, N.Y. TIMES, Apr. 14, 2010, at A17.

32. See Christopher C. Jennings \& Katherine J. Hayes, Health Insurance Reform and the Tensions of Federalism, 362 NEW ENG. J. MED. 2244, 2245 (2010); Jennifer Haberkorn, Party-Line Split on High-Risk Pools, POLITICO (May 3, 2010, 4:38 AM EDT), http://www.politico.com/ news/stories/0510/36662.html.

33. See N.Y. State Conference of Blue Cross \& Blue Shield Plans v. Travelers Ins. Co., 514 U.S. 645,661 (1995) ("[G]eneral health care regulation . . . historically has been a matter of local concern."); infra Part IV.B (discussing high-risk insurance pools).

34. See, e.g., Rosenbaum, supra note 28 , at 1954 (noting that the legal claims are largely frivolous). But see supra note 30 and accompanying text (describing states' successful constitutional challenge in a Florida federal court).

35. Timothy S. Jost, Can the States Nullify Health Care Reform?, 362 NEW ENG. J. MED. 869, 869 (2010).

36. See G. Alan TARR, Understanding STATE CONSTitutions 23 (1998) (noting that the Constitution has been amended less than once per decade, compared to states, which regularly amend and revise their constitutions); Daniel B. Rodriguez, State Constitutionalism and the Domain of Normative Theory, 37 SAN DIEGo L. REV. 523, 527 (2000) ("The . . key distinction between the federal and state constitutions concerns the frequency of amendments over time."); Lawrence G. Sager, The Incorrigible Constitution, 65 N.Y.U. L. REV. 893, 895 (1990) ("[T] markedly obdurate to textual change.").

37. See Frank B. Cross, Realism About Federalism, 74 N.Y.U. L. REV. 1304, 1306-07 \& n.10 (1999) (citing various historical examples during the New Deal); Ernest A. Young, Welcome to the Dark Side: Liberals Rediscover Federalism in the Wake of the War on Terror, 69 BROOK. L. REV. 1277, 1283 \& nn.18-19 (2004) (describing the Virginia and Kentucky Resolutions, which protested Congress' Alien and Sedition Acts).

38. See Ann Althouse, The Vigor of Anti-Commandeering Doctrine in Times of Terror, 69 BROOK. L. REV. 1231, 1253-57 (2004) (noting a movement against the PATRIOT Act in Madison, Wisconsin); Young, supra note 37, at 1278, 1282-83, 1285-86 (describing the movement by states 
health care "'tariff of abominations," figures seem laughable. ${ }^{42}$ Nevertheless, the nullification movement continues to gather steam. Rather than dismiss the trend, its persistence and pervasiveness warrants consideration. This Article identifies the potential value to the national health care conversation and federal-state relations deriving from the federalism objections being voiced by health reform opponents.

\section{FEDERALISM THEORIES}

To develop a concept of rhetorical federalism, this Part engages two plausible working theories, borrowing the normative posture of one, which suggests that state resistance to federal policies can be a good thing, and the descriptive posture of another, observing that federalism arguments may be mere proxies for substantive policy objections. The normative theory, uncooperative federalism, posits that even when states obstruct or refuse to cooperate with federal authorities, the contentious interactive process may benefit policymaking. ${ }^{43}$ The descriptive theory, opportunistic federalism, dismisses arguments invoking states' rights or structure of government as disingenuous and simply means to other ideological ends. ${ }^{44}$ Each theory begins to rationalize the array of state responses to ACA, but neither provides a fully operative explanation for the current health reform nullification movement. Rhetorical federalism seconds the normative conclusion of uncooperative federalism that state-

in opposing the PATRIOT Act).

39. See, e.g., Sean Murphy \& Tim Talley, Oklahoma Tea Parties, Lawmakers Envision AntiFederal Militia, TRIB.COM (Apr. 13, 2010, 12:00 AM), http://trib.com/news/national/article_ 3b9b65ba-b60c-507a-9c9e-f076a95b1649.html.

40. See John Yoo, Andrew Jackson and Presidential Power, 2 CHARLESTON L. ReV. 521, 563-72 (2008) (describing President Andrew Jackson's nullification and secession fight with South Carolina over national tariff rates).

41. See William H. Chafe, The Unfinished Journey: America Since World War II 157-61 (3d ed. 1995) (describing Southern resistance to the school desegregation mandate in Brown v. Board of Education, and the subsequent order of Arkansas Governor Orval Faubus to block the entrance to Little Rock's Central High School).

42. See Tim Jost, Firing Again on Fort Sumter, O'NeILl INST. FOR NAT'L \& GLOBAL HEALTH L. (Sept. 29, 2009, 7:35 AM), http://oneillhealthreform.wordpress.com/2009/09/29/firingagain-on-fort-sumpter/; Frank Pasquale, Parsing "Populism" in Resistance to Reform, HEALTH REFORM WATCH (Sept. 28, 2009), http://www.healthreformwatch.com/2009/09/28/parsingpopulism-in-resistance-to-reform/.

43. See Jessica Bulman-Pozen \& Heather K. Gerken, Uncooperative Federalism, 118 YALE L.J. 1256, 1286-91 (2009) (discussing the various ways that uncooperative federalism benefits policymaking); infra Part III.A.

44. See Cross, supra note 37 , at 1307 \& $\mathbf{n} .12$ (citing instances where federalism was used to pursue other ideological ends); Neal Devins, The Judicial Safeguards of Federalism, 99 Nw. U. L. REV. 131, 137 (2004); infra Part III.B. 
based dissent can be valuable, yet acknowledges the descriptive accuracy of opportunistic federalism that some of the rhetoric may be disingenuous.

Mindful of Larry Kramer's admonition, "Talking about federalism feels a bit like joining the proverbial blind men trying to describe an elephant. It's such a big topic, one can't possibly hope to grasp more than a small part of the beast," 45 I offer a detailed case study of the role of federalism in health care decisionmaking and aim to grasp only the particular resonance of state resistance in the current health reform conversation. Presidential administrations over the past century, again and again, have attempted to enact meaningful, comprehensive health care reform plans. ${ }^{46}$ ACA represents "the most significant change in the American health care system in a generation," $" 47$ and the role of state resistance in the passage and implementation of that law is notable. I leave to future scholars to consider whether the insights that I develop in the health reform context apply similarly to future significant legislative events.

\section{A. Uncooperative Federalism}

Uncooperative federalism, a theory articulated by Jessica BulmanPozen and Heather Gerken, ${ }^{48}$ suggests that even when states actively refuse to cooperate with the federal government, their resistance may be beneficial. ${ }^{49}$ To understand uncooperative federalism, it is helpful to place the theory in the context of other federalism theories. BulmanPozen and Gerken offer the following matrix, which I slightly modify, in their footnote $18 .^{50}$

45. Larry Kramer, Understanding Federalism, 47 VAND. L. REV. 1485, 1485 (1994).

46. See U.S. Health Care Reform Interactive Timeline, NEW ENG. J. MED.: HEALTH POL'Y \& REFORM (Aug. 26, 2009), http://healthpolicyandreform.nejm.org/?page_id=1647.

47. Barry R. Furrow et al., Health Care Reform Supplement to health law: CASES, MATERIALS, AND PROBLEMS 1 (6th ed. 2010).

48. See generally Bulman-Pozen \& Gerken, supra note 43 (describing the concept of uncooperative federalism in theory and in practice, illustrating the advantages of this state-centered dissent, and advocating for a strong commitment to this type of federalism).

49. See id. at 1286-91.

50. See id. at 1264 n. 18 . 
Table 1

\begin{tabular}{|l|l|l|}
\hline STATES'ROLE & Power of the sovereign & $\begin{array}{l}\text { Power of the } \\
\text { servant }\end{array}$ \\
\hline Rivals/challengers & $\begin{array}{l}\text { 1. State autonomy; dual } \\
\text { sovereignty }\end{array}$ & $\begin{array}{l}\text { 2. Uncooperative } \\
\text { federalism }\end{array}$ \\
\hline Allies/friends & 3. Functional theory & $\begin{array}{l}\text { 4. Cooperative } \\
\text { federalism }\end{array}$ \\
\hline
\end{tabular}

The vertical axis represents the normative position of what states should do: either they should serve as rivals or challengers to the federal government, or they should serve as friends or allies with the federal government. The horizontal axis identifies two strategies to facilitate healthy federal-state relations: either the power of states as sovereigns, or the power of states as servants. The authors note that most existing scholarship falls in Box 1, the state autonomy or dual sovereignty view of federal-state relations, or Box 4 , the cooperative federalism view. ${ }^{51}$ Their theory fills Box 2, the affirmative case for states as rivals and challengers from the posture of servants.

For Box 3, Bulman-Pozen and Gerken suggest Roderick Hills's "functional theory." 52 Hills favors state autonomy not so that states can operate as dual or separate sovereigns, but so that they can bargain effectively for their role within a cooperative, integrated federal regime. ${ }^{53}$ States, under their reserved powers, hold a property right to refuse to lend state administrative processes to implement federal policies, which right they can sell in a freely negotiated trade, like any other private contractor. ${ }^{54}$ Cooperation is a good thing, but only when the federal government "purchases" state services through voluntary agreements.

Dual sovereignty or state autonomy, like uncooperative federalism, urges states to rival and challenge the federal government but from the posture of sovereign powers. ${ }^{55}$ Values associated with the dual

51. Id.

52. See id.; see also Roderick M. Hills, Jr., The Political Economy of Cooperative Federalism: Why State Autonomy Makes Sense and "Dual Sovereignty" Doesn't, 96 MiCH. L. REV. 813, 816-17 (1998) [hereinafter Hills, State Autonomy] (defining the functional theory generally); Roderick M. Hills, Jr., Federalism in Constitutional Context, 22 HARV. J.L. \& PUB. POL'Y 181, 185 (1998) [hereinafter Hills, Federalism] ("[N]on-federal governments have the capacity to bargain hard for more implementing discretion or more federal money, or both, when they enlist to implement federal programs.").

53. See Hills, State Autonomy, supra note 52, at 817 .

54. Id. at 822-23. Hills calls this property right "'the New York entitlement." Id. at 822; see New York v. United States, 505 U.S. 144, 161 (1992) (articulating the anticommandering principle).

55. See Akhil Reed Amar, Five Views of Federalism: "Converse-1983" in Context, 47 VAND. L. REV. 1229, 1236-37 (1994) [hereinafter Amar, Five Views]; Akhil Reed Amar, Of Sovereignty 
sovereignty view include providing alternative, more accessible forums for citizen participation in the political process. ${ }^{56}$ In addition, different territories may have different tastes and needs, especially on social policy matters. ${ }^{57}$ The diversity of approaches creates a "political market," allowing citizenry a choice of "laws, customs, and attitudes," and ultimately, exit rights. ${ }^{59}$ States also serve as laboratories of democracy, experimenting and crafting solutions to problems, which approaches can be borrowed by other states and the federal government. $^{60}$

and Federalism, 96 YALE. L.J. 1425, 1492-93 (1987) [hereinafter Amar, Of Sovereignty]; BulmanPozen \& Gerken, supra note 43, at 1260-62; Barry Friedman, Valuing Federalism, 82 MNN. L. REV. 317, 330 (1997); Young, supra note 37, at 1297.

56. See Garcia v. San Antonio Metro. Transit Auth., 469 U.S. 528, 575 \& n.18 (1985) (Powell, J., dissenting) ("The Framers recognized that the most effective democracy occurs at local levels of government, where people with firsthand knowledge of local problems have more ready access to public officials ...."); Amar, Five Views, supra note 55, at 1234 ("[F]ederalism operates to edify and engage the citizenry."); Erwin Chemerinsky, The Values of Federalism, 47 FLA. L. REV. 499, 527 (1995) ("[T]o the extent the electorate is small, and elected representatives are thus more immediately accountable to individuals and their concerns, government is brought closer to the people, and democratic ideals are more fully realized."); Betsy J. Grey, The New Federalism Jurisprudence and National Tort Reform, 59 WASH. \& LEE L. REV. 475, 511 (2002) ("[Federalism] fosters governments that are more responsive than Congress to the needs of local citizens ....").

57. See Alan R. Weil \& James R. Tallon, Jr., The States' Role in National Health Reform, 36 J.L. MED. \& ETHICS 690, 690 (2008) ("[S]tate policies can be more closely tailored to local economic conditions and can reflect local values ....").

58. Amar, Five Views, supra note 55, at 1237-38; Emest A. Young, The Rehnquist Court's Two Federalisms, 83 TEX. L. REV. 1, 54 (2004) ("[T]he best way to please more of the people more of the time is to offer a choice of regulatory regimes.").

59. See Gregory v. Ashcroft, 501 U.S. 452, 458 (1991) ("[Dual sovereignty] makes government more responsive by putting the States in competition for a mobile citizenry."); Richard A. Epstein, Exit Rights Under Federalism, 55 L. \& ConTEMP. PROBS. 147, 150 (1992) ("Federalism works best where it is possible to vote with your feet."); Justin Long, Intermittent State Constitutionalism, 34 PEPP. L. REV. 41, 101 (2006) ("Diversity among the states also permits mobile Americans to vote with their feet.").

60. See New State Ice Co. v. Liebmann, 285 U.S. 262, 311 (1932) (Brandeis, J., dissenting) ("It is one of the happy incidents of the federal system that a single courageous State may, if its citizens choose, serve as a laboratory; and try novel social and economic experiments without risk to the rest of the country."); Amar, Five Views, supra note 55, at 1233-34; Chemerinsky, supra note 56 , at 528 ("A final argument that is frequently made for protecting federalism is that states can serve as laboratories for experimentation."); James A. Gardner, The "States-As-Laboratories" Metaphor in State Constitutional Law, 30 VAL. U. L. REV. 475, 486-87 (1996) (suggesting that the states-as-laboratories approach produces potentially valuable information about policy alternatives); Grey, supra note 56, at 512 (recognizing Justice Brandeis' observation of the state as a laboratory); Long, supra note 59, at 56 (summarizing the "laboratories of democracy" rationale for independent judicial interpretation of state constitutions); Robert F. Rich \& William D. White, Federalism and Health Care Policy, 1998 U. ILL. L. REV. 861,868 ("[S]tates have amply demonstrated an ability to come up with innovative new solutions and act as 'laboratories of democracy' in important social policy areas like health care."). 
The dual sovereignty scholarship recognizes the value of dissent, especially state-level dissent, within the federal system. ${ }^{61}$ Dissent "contributes to the marketplace of ideas, engages electoral minorities[,] ... and facilitates self-expression." 62 The Framers envisioned friction, clashes, and jarring as part of the constitutional design. ${ }^{63}$ States may act as lobbyists and litigants, challenging federal policies and laws. ${ }^{64}$ Objections may be voiced by states qua states, ${ }^{65}$ or by states as spokespersons for individuals. ${ }^{66}$

Cooperative federalism, by contrast, envisions the federal government and states working together as partners to address common problems or implement legislation. ${ }^{67}$ States serve as supportive allies, freely and voluntarily, albeit often with strong encouragement, implementing federal policies. ${ }^{68}$ Conditional spending programs, ${ }^{69}$ such

61. See, e.g., CASS R. SUnStein, Why Societies NeEd DisSENT 145 (2003) ("American founders' largest contribution consisted in their design of a system that would ensure a place for diverse views in government."); Friedman, supra note 55, at 403-04; James A. Gardner, State Constitutional Rights as Resistance to National Power: Toward a Functional Theory of State Constitutions, 91 GEO. L.J. 1003, 1007 (2003); Heather K. Gerken, Dissenting by Deciding, 57 STAN. L. REV. 1745, 1752-59 (2005) (discussing different regional ideologies in states); Matthew C. Porterfield, State and Local Foreign Policy Initiatives and Free Speech: The First Amendment as an Instrument of Federalism, 35 STAN. J. INT'L L. 1, 2-4 (1999) (noting that freedom of expression is a vehicle upon which states check the power of the federal government); Young, supra note 37, at 1282-83 (discussing instances in which states have opposed federal policies).

62. Gerken, supra note 61 , at 1749 .

63. See THE Federalist No. 70, at 426-27 (Alexander Hamilton) (Clinton Rossiter ed., 1961) ("[D]ifferences of opinion, and the jarring of parties... often promote deliberation and circumspection, and serve to check the excesses in the majority.").

64. See Deborah Jones Merritt, The Guarantee Clause and State Autonomy: Federalism for a Third Century, 88 COLUM. L. REV. 1, 5-6 (1988).

65. See, e.g., Porterfield, supra note 61 , at 3-5 (noting that states have taken on issues innately federal, such as foreign policy, in order to advocate their own views).

66. See Amar, Of Sovereignty, supra note 55, at 1446 (noting that the Framers conceptualized states as sovereign factions that could act on their own behalf or on the behalf of the state citizenry); Young, supra note 37 , at 1285-86 (arguing that states should act as intermediaries between the people and the federal government).

67. See New York v. United States, 505 U.S. 144, 167-68 (1992) (describing the cooperative federalism model); Steward Mach. Co. v. Davis, 301 U.S. 548, 590-91 (1937) (noting that taxation by the federal government promotes both federal and state welfare); see also Bulman-Pozen \& Gerken, supra note 43, at 1262 (illustrating the integration component of cooperative federalism by comparing the theory to a marble cake); Hills, State Autonomy, supra note 52, at 858-60 (exemplifying the concept of conditional grants, in which the federal government gives states money to be used for the welfare of the state, as an example of cooperative federalism); Philip J. Weiser, Towards a Constitutional Architecture for Cooperative Federalism, 79 N.C. L. REV. 663, 668-70 (2001) (describing history and examples of cooperative federalism, beginning with New Deal legislation).

68. See William W. Buzbee, Asymmetrical Regulation: Risk, Preemption, and the Floor/Ceiling Distinction, 82 N.Y.U. L. REV. 1547, 1550 (2007) ("[C]ooperative federalism [programs] ... typically involve a federal statute that regulates a risk or addresses a social ill or need ... [but] do not depend solely on federal actors for their implementation and enforcement."); 
as Medicaid, are prime examples of cooperative federalism. ${ }^{70}$ Under its spending power, Congress entices states to enact laws or implement programs by conditioning federal funding on states' compliance with broad federal requirements, ${ }^{71}$ even though the federal government cannot directly regulate states or "commandeer" state regulatory authorities to implement, administer, or enforce federal programs. ${ }^{72}$ ACA employs several cooperative federalism strategies, including conditional spending, conditional preemption, grants, and contracts, to engage state cooperation in implementing the massive package of health care reforms. $^{73}$

Uncooperative federalism focuses on the power that states wield precisely because of their subservient posture vis-à-vis the federal government. ${ }^{74}$ The theory emphasizes the "power of the servant" and "the ways in which integration can serve as a distinct source of strength."75 Lacking adequate financial resources or regulatory reach to implement comprehensive programs, the federal government often

Evan Caminker, The Unitary Executive and State Administration of Federal Law, 45 U. KAN. L. REV. 1075, 1075 (1997) ("Congress frequently encourages states to become regulatory partners in federal programs, sometimes by threatening to preempt the existing regulations of non-participating states, and other times by rewarding participating states with substantial monetary subsidies."); Susan Rose-Ackerman, Cooperative Federalism and Co-optation, 92 YALE L.J. 1344, 1346 (1983) (using Medicaid as an example of states furthering federal policy); Joshua D. Sarnoff, Cooperative Federalism, the Delegation of Federal Power, and the Constitution, 39 ARIZ. L. REV. 205, 213-14 (1997); Frank R. Strong, Cooperative Federalism, 23 IOWA L. REV. 459, 479-82 (1938) (describing states' food and drug legislation as compared to federal legislation).

69. See New York, 505 U.S. at 167 (citing cases that exemplify use of the conditional spending power); South Dakota v. Dole, 483 U.S. 203, 210-12 (1987) (conditioning federal highway funds on states enacting laws limiting alcohol sales to minors and introducing limits on conditional spending power); Helvering v. Davis, 301 U.S. 619, 640 (1937) (defining the concept of conditional spending power); United States v. Butler, 297 U.S. 1, 65 (1936) (illustrating Congress' power to lay and collect taxes); Weiser, supra note 67, at 705 (describing various cooperative federalism schemes).

70. See Harris v. McRae, 448 U.S. 297, 308 (1980) ("The Medicaid program... is a cooperative endeavor in which the Federal Government provides financial assistance to participating States to aid them in furnishing health care to needy persons.").

71. See Dole, 483 U.S. at 207 ("[O]bjectives not thought to be within Article I's 'enumerated legislative fields' may nevertheless be attained through the use of the spending power and the conditional grant of federal funds." (quoting Butler, 297 U.S. at 65)); Pennhurst State Sch. \& Hosp. v. Halderman, 451 U.S. 1, 17 (1981) ("[O]ur cases have long recognized that Congress may fix the terms on which it shall disburse federal money to the States.").

72. See Printz v. United States, 521 U.S. 898, 925 (1997) ("[T]he Federal Govemment may not compel the States to implement, by legislation or executive action, federal regulatory programs."); New York, 505 U.S. at 162 ("[T] Constitution has never been understood to confer upon Congress the ability to require the States to govern according to Congress' instructions.").

73. See, e.g., Patient Protection and Affordable Care Act, Pub. L. No. 111-148, $\S 1002$, 1321, 1323(e), 1331, 9005, 124 Stat. 119, 138-39, 186-87, 196-200, 854-55 (2010).

74. See Bulman-Pozen \& Gerken, supra note 43, at 1263.

75. Id. at 1265 . 
depends on states to implement and administer federal policies. ${ }^{76}$ Because Congress cannot simply mandate states to administer federal programs, it must offer carrots, such as conditional funding or block grants, or sticks, such as conditional preemption or threats to usurp state implementation. $^{77}$ In so doing, the federal government cedes considerable power and discretion to states. For example, under Medicaid, states must comply with broad federal requirements but otherwise are free to tailor their state plans to meet their citizens' particular needs, still receiving federal matching dollars for every state dollar spent. ${ }^{78}$ Even though the federal government ultimately holds the threat of revoking federal funds or taking over state programs, financial, political, and practical realities may render that threat an empty one. ${ }^{79}$

States' power as servants also derives from their integration into federal program implementation. ${ }^{80}$ State regulators and policymakers have regular interaction with federal authorities in administering complex, cooperative programs. State actors may develop subject-matter specialization within certain areas, such as environmental or health policy, which transcends federal and state lines of authority. ${ }^{81}$ A related source of power derives from the fact that states serve two masters: the federal government and their state constituents. ${ }^{82}$ Voters' dissenting views give states the political will and capital to challenge federal policies.

Bulman-Pozen and Gerken conclude that uncooperative federalism can be useful within a well-functioning federal system. ${ }^{83}$ Friction between the federal government and states fosters a rich dialogue, clarifies accountability, and encourages political participation. ${ }^{84}$ Doctrinal implications of the uncooperative federalism theory suggest that commandeering, which is considered unacceptably intrusive on state autonomy to Box 1 adherents, perhaps should be allowed or encouraged under Box 2 because it engenders dissent. ${ }^{85}$ Uncooperative federalism, like state autonomy or dual sovereignty, prefers narrow preemption but not because state power should be interpreted as broadly as possible but,

76. See id. at $\mathbf{1 2 6 7 .}$

77. See Timothy Stoltzfus Jost, Health Insurance Exchanges: Legal Issues, J.L. MED. \& ETHICS, Fall 2009, at 53, 56.

78. See Rose-Ackerman, supra note 68, at 1346.

79. See Bulman-Pozen \& Gerken, supra note 43, at 1267.

80. See id. at $1268-69$.

81. See id.

82. See id. at 1270 .

83. See id. at 1307.

84. See id. at 1286-90.

85. See id. at 1297. 
rather, as a way to create larger overlapping spheres of federal and state regulatory authority thereby ensuring ongoing conflict and jarring. ${ }^{86}$

The authors are equivocal on the value of conditional spending programs like Medicaid in advancing the uncooperative federalism thesis. ${ }^{87}$ The amount of power that states wield as servants under conditional spending schemes depends on how badly states need the federal money. If states have no real choice but to accept the federal funds, conditional spending essentially becomes commandeering, sparking various forms of beneficial state resistance and dissent. ${ }^{88}$ But if states can freely decline the federal government's offer or bargain for additional terms, little meaningful dialogue remains. States that freely opt-out of cooperative federalism programs have little reason to object, while states that bargain effectively may have their objections appeased. $^{89}$

Bulman-Pozen and Gerken offer the beginnings of a working theory and invite additional case studies and doctrinal articulation. ${ }^{90}$ This Article engages that invitation in the context of federal health reform, accepting the normative position but finding the descriptive, and predictive, suggestions not entirely apt. ACA relies heavily on states to implement various key components over the next several years and maintain those structures and laws perpetually. As the uncooperative federalism model predicts, states, in their posture as federal servants, have objected to various provisions of new federal law. ${ }^{91}$ But they have been unable to wield much power. They also have passively accepted provisions of the law that impose significant burdens and intrude deeply on state terrain. At the same time, states invoke the rhetoric of federalism to object to ACA provisions that barely implicate state power or responsibility at all, ${ }^{92}$ a response that seems to fall outside of the uncooperative federalism model.

\section{B. Opportunistic Federalism}

Another plausible explanation for state resistance to federal health reform is opportunistic federalism, a view that comports with those who dismiss the nullification movement as petty politics. Opportunistic

86. See id. at 1304 .

87. See id. at $1300-02$.

88. See id. at 1300 .

89. See id. at 1301

90. See id. at 1308-09.

91. See id. at 1271-72 (discussing the different types of dissent in which states may engage).

92. See Huq, supra note 28 (noting the different constitutional arguments advanced by the states opposing the ACA). 
federalism is not a distinctly articulated theory but a theme observed by various scholars. ${ }^{93}$ The idea is that opponents of particular policies invoke federalism as the basis for their objections although, in reality, they care very little about the structural allocation of power between states and the federal government. Federalism arguments are mere proxies for substantive objections to particular laws and policies.

Opportunistic invocation of federalism to advance political positions has a long history in the United States, beginning with southern states' resistance to abolition and, later, desegregation. ${ }^{94}$ Frank Cross maintains, "federalism is consistently (and I contend inherently) employed only derivatively, as a tool to achieve some other ideological end, rather than as a principled end in and of itself." ${ }^{95}$ He observes this trend among not only voters and politicians but also judges. ${ }^{96}$ Other scholars focus on the role of courts as protectors of structural federalism against opportunistic federalism by voters, special interest groups, and politicians. ${ }^{97}$ Neal Devins observes that:

[T]he willingness of lawmakers and interest groups to manipulate federalism in order to secure preferred substantive policies is the rule.

93. See, e.g., Lynn A. Baker \& Sanford Levinson, Twenty-Year Legacy of South Dakota v. Dole: Dole Dialogue, 52 S.D. L. REV. 468, 487 (2007) ("[O]pportunistic embrace of federalism when it is convenient to attaining one's substantive ends is quite different from a more general commitment to federalism, where one would have to take the quite-often bitter with the onlysometimes sweet."); Tim Conlan, From Cooperative to Opportunistic Federalism: Reflections on the Half-Century Anniversary of the Commission on Intergovernmental Relations, 66 PUB. ADMIN. REV. 663, 667 (2006) ("By opportunistic, I mean a system that allows--and often encouragesactors in the system to pursue their immediate interests with little regard for the institutional or collective consequences."); Marc R. Poirier, Same-Sex Marriage, Identity Processes, and the Kulturkampf: Why Federalism Is Not the Main Event, 17 TEMP. POL. \& CIV. RTS. L. REV. 387, 400 (2008) ("There will certainly be opportunistic federalism-gamesmanship in framing arguments about what level of jurisdiction to apply to a resource, where various positions are motivated by the perception that one level of regulation-local, state, federal, or international-will as a practical matter be more favorable to a particular desired overall result than another." (footnote omitted)); Erin Ryan, Federalism and the Tug of War Within: Seeking Checks and Balance in the Interjurisdictional Gray Area, 66 MD. L. REV. 503, 598-600 (2007) (describing opportunistic federalism in American history).

94. See Cross, supra note 37, at 1306 ("Federalism's role in American history as a stalking horse for racism is infamous."); Devins, supra note 44, at 134 ("This pattern of shifting constitutional positions on federalism runs throughout American history."); Ryan, supra note 93, at 598 ("Among the more famous examples of such federalism opportunism is the role reversal between pro-slavery and abolitionist interests before and after the Civil War."); see also Cooper v. Aaron, 351 U.S. 1, 4 (1958) (rejecting Arkansas's contention that its governor and legislature were not bound by desegregation mandates).

95. Cross, supra note 37 , at 1307.

96. See id. at 1308-11.

97. See Devins, supra note 44 , at 137 ; John O. McGinnis \& Ilya Somin, Federalism vs. States' Rights: A Defense of Judicial Review in a Federal System, 99 Nw. U. L. REv. 89, 121 (2004). 
Indeed, the historical record is so overwhelming that it is hard to believe that a majority of informed voters would suspend their personal policy preferences in order to reap the benefits of structural federalism. $^{98}$

Given that federalism is undervalued in the political process, Devins calls on courts to police structural federalism, ${ }^{99}$ urging the Supreme Court, in particular, to "ratchet up" its reinvigoration of federalism. 100

John McGinnis and Ilya Somin agree that the political process fails to protect federalism values. The problem, they contend, is not necessarily that voters do not value federalism, but that elected representatives are not politically motivated to protect structural federalism. ${ }^{101}$ "Elected officials invoke federalism when it comports with their substantive policy preferences, but they otherwise do not care about the federal-state balance." 102 McGinnis and Somin suggest that if voters were knowledgeable and adequately informed about federalism values they might, in certain cases, subordinate other policy preferences in favor of preserving the structure of government. ${ }^{103}$ But the system breaks down because politicians, acting as agents for their voter principals, "have systematic political interests that often cause them to undermine federalism." 104 Voters" "rational ignorance" of the "complex issue" of structural federalism means that they will not push elected representatives to protect those values. ${ }^{105} \mathrm{McGinnis}$ and Somin note:

Federalism is an abstract and complicated system compared to many underlying public policy issues like drugs and education, which are more concrete and more likely to engage the passions of citizens. Thus, when a federalism issue becomes a matter of public controversy, it almost always focuses on the specific policy question at hand than on federalism more generally. ${ }^{106}$

Because neither state nor federal officials stand to gain politically by protecting federalism, courts must step in. ${ }^{107}$ The authors clarify from the outset that they are agnostic on strong state versus strong federal

98. Devins, supra note 44 , at 134 .

99. Id. at 137 .

100. Id. at 139 .

101. See McGinnis \& Somin, supra note 97, at 103 (noting that politicians have their own "systematic political interests").

102. Devins, supra note 44 , at 137.

103. See McGinnis \& Somin, supra note 97 , at $94-97$ (discussing why the general citizenry lacks fundamental knowledge about federalism-related issues).

104. Id. at 103 .

105. Id. at 90, 94-97.

106. Id. at 96.

107. See id. at 97. 
power; the federalism that they seek to protect is simply the constitutional allocation of power. ${ }^{108}$

Erin Ryan also describes the pervasiveness of opportunistic federalism in judicial and political contexts but ultimately concludes that concern for structural federalism is earnest. She asserts that "our continued commitment to structural tension between local and national authority must stem from a conviction that it confers important architectural advantages" beyond federalism's historical origins or political preferences. ${ }^{109}$ But Ryan cautions us not to assume that Americans necessarily or consistently place high importance on federalism, describing numerous examples of opportunistic federalism, beginning with the Louisiana Purchase. ${ }^{110}$ Ryan observes that federalism "is inherently content-neutral with regard to substantive political issues" and acknowledges other scholars' observations that political preferences tend to trump governmental structure preferences. ${ }^{111}$ Despite strong evidence of opportunistic federalism, Ryan maintains, for the sake of her argument, that the electorate does, in fact, value federalism as a policyneutral, structural matter. ${ }^{12}$ She then articulates a model of balanced federalism for resolving inherent tension between federal and state authority. $^{113}$

For the sake of comparison, I offer a normative-descriptive two-bytwo matrix similar to Bulman-Pozen and Gerken's, ${ }^{114}$ to place opportunistic federalism within existing scholarship and identify the box that rhetorical federalism fills:

Table 2

\begin{tabular}{|l|l|l|}
\hline $\begin{array}{l}\text { FEDERALISM } \\
\text { ARGUMENTS }\end{array}$ & Opportunistic & Earnest \\
\hline Detrimental & $\begin{array}{l}\text { 1. Opportunistic } \\
\text { federalism }\end{array}$ & $\begin{array}{l}\text { 2. Nationalist } \\
\text { perspective; unitary } \\
\text { state }\end{array}$ \\
\hline Beneficial & $\begin{array}{l}\text { 3. Rhetorical } \\
\text { federalism }\end{array}$ & $\begin{array}{l}\text { 4. Our federalism; } \\
\text { new federalism }\end{array}$ \\
\hline
\end{tabular}

108. See id. at 89-90.

109. Ryan, supra note 93 , at 597.

110. Id. at 598 .

111. Id.

112. See id.

113. See id. at 644-65.

114. See Bulman-Pozen \& Gerken, supra note 43, at 1264 n. 18 . 
The horizontal axis describes federalism arguments as either opportunistic or earnest. The vertical axis represents the normative position that such arguments are either detrimental or beneficial to "healthy federal-state relations." 115 Opportunistic federalism occupies Box 1 , representing the view that political invocation of federalism arguments fails to protect structural values. I place rhetorical federalism in Box 3 to express my conclusion that even disingenuous, politically opportunistic arguments are potentially valuable to both federal-state relations and health care decisionmaking. The rhetoric of federalism also occupies Box 4, which represents earnest appeals to traditional values of "Our Federalism"" 116 and more recent "new federalism" scholarship. ${ }^{117}$ To complete the matrix, Box 2 represents the view that even earnest appeals to federalism values may be detrimental, including the nationalist perspective ${ }^{118}$ and proponents of a unitary system of government. 119

Our Federalism expresses the Framers' constitutional design, balancing centralized coordination at the national level, on the one hand, and diffusion of power and respect for state sovereignty, on the other. ${ }^{120}$ Ample scholarly literature, beginning with the Founding Fathers' Federalist Papers, identifies the values of a federal system. ${ }^{121}$ Just as horizontal division of power among the three branches of government provides checks and diffuses power, so too does vertical division

115. Id.

116. Younger v. Harris, 401 U.S. 36, 44-45 (1971) (discussing the historic notions of American federalism).

117. See infra notes $126-38$ and accompanying text.

118. See Amar, Five Views, supra note 55, at 1230-31 (describing nationalist perspective, which views states as threats to constitutional liberty and favors stronger central government); Hills, State Autonomy, supra note 52, at 831-32 (describing nationalistic theory).

119. See Daniel J. Elazar, Contrasting Unity and Federal Systems, 18 INT'L POL. SCI. REv. 237, 243-44 (1997) (describing and offering France and the United Kingdom as examples of unitary states, identified by "efficient control of power").

120. See, e.g., Printz v. United States, 521 U.S. 898, 918-19 (1997) ("It is incontestible [sic] that the Constitution established a system of 'dual sovereignty.'”); South Carolina v. Baker, 485 U.S. 505, 531, 533 (1988) (O'Connor, J., dissenting) ("'If there is any danger, it lies in the tyranny of small decisions-in the prospect that Congress will nibble away at state sovereignty, bit by bit, until someday essentially nothing is left but a gutted shell."' (quoting LAURENCE H. TRIBE, AMERICAN CONSTITUTIONAL LAW § 5-20, at 381 (2d. ed. 1988))); Hills, State Autonomy, supra note 52, at 816 ("The national government has unique needs in maintaining the supremacy of federal law and an orderly federal system, yet there must be a limit to federal power and a corresponding reservoir of state power if federalism is to have any meaning at all.").

121. See, e.g., ThE FEDERALIST No. 45, at 292-93 (James Madison) (Clinton Rossiter ed., 1961) ("The powers delegated by the proposed Constitution to the federal government are few and defined. Those which are to remain in the State governments are numerous and indefinite."); Young, supra note 57, at 59 (citing James Madison). 
between the federal government and the states. ${ }^{122}$ States retain vast reserved powers and broad discretion to carry out policy objectives. ${ }^{123}$ The Framers recognized that states bear primary responsibility for governance. ${ }^{124}$ Health, welfare, and safety fall squarely within states' traditional reserved powers. ${ }^{125}$

States' reserved powers offer unique opportunities for states to address social policy concerns. ${ }^{126}$ The Constitution establishes a floor, requiring states to recognize at least that level of protection to individual rights. But states may exceed the federal floor and accord even greater protection. $^{127}$ Justice William Brennan, in a series of articles, expressly

122. See Printz, 521 U.S. at 921-22; Gregory v. Ashcroft, 501 U.S. 452, 458 (1991); Amar, Five Views, supra note 55, at 1236 (citing Fed. Energy Regulatory Comm'n v. Mississippi, 456 U.S. 742, 790 (1982) (O'Connor, J., concurring in part, dissenting in part)); Amar, Of Sovereignty, supra note 55, at 1439, 1443; Chemerinsky, supra note 56, at 525; Gardner, supra note 61, at 1007; Herbert Wechsler, The Political Safeguards of Federalism: The Role of States in the Composition and Selection of the National Government, 54 COLUM. L. REV. 543, 543-44 (1954).

123. See Gibbons v. Ogden, 22 U.S. (9 Wheat.) 1, 203-04 (1824) ("[P]ower remaining with the States ... form[s] a portion of that immense mass of legislation, which embraces everything within the territory of a State, not surrendered to the general government .....").

124. See THE Federalist No. 45, at 319 (James Madison) (E. Bourne ed., 1947); THE FEDERALIST No. 17, at 113 (Alexander Hamilton) (E. Boume ed., 1947); see also Chemerinsky, supra note 56, at 525 ("The Framers envisioned that the vast majority of governance would be at the state and local levels and that federal actions would be relatively rare and limited.").

125. See United States v. Lopez, 514 U.S. 549, 564, 581-82, 594 (1995); Jacobson v. Massachusetts, 197 U.S. 11, 24-25 (1905) ("[T]he authority of a State to enact quarantine laws and 'health laws of every description[]' ... relate to matters completely within its territory and which do not by their necessary operation affect the people of other States.").

126. See Daniel J. Elazar, ThE AMERICAN CONSTITUTIONAL TRADITION 113 (1988) ("[S] tate constitutions are important determinants of who gets what, when, and how in America ...."); TARR, supra note 36, at 149 (describing states' early recognition of responsibility for social welfare); Daniel Gordon, Superconstitutions Saving the Shunned: The State Constitutions Masquerading as Weaklings, 67 TEMP. L. REV. 965, 970 (1994) ("[S]tate constitutions serve as the predominant source of protection for individual rights in the United States .... .); Paul W. Kahn, State Constitutionalism and the Problems of Fairness, 30 VAL. U. L. REV. 459, 464 (1996) (observing that states have the opportunity to address faimess controversies not being resolved satisfactorily at the federal level).

127. See Amar, Five Views, supra note 55, at 1244 ("[T] a minimum baseline - a floor-that state judges must respect on penalty of reversal. But the floor need not become a ceiling."); Buzbee, supra note 68, at 1555 ("[F]ederal floors retain the benefits of multiple regulatory voices, protections, and diverse regulatory modalities."); Gardner, supra note 60, at 483 (citing Cruzan v. Dir., 497 U.S. 261, 292 (1990) (O’Connor, J., concurring)); Hans A Linde, Without "Due Process": Unconstitutional Law in Oregon, 49 OR. L. REV. 125, 182 (1970) (urging examination of civil rights claims arising under state constitutions before turning to federal protections); Long, supra note 59, at 51 ("[S]tate courts are legally entitled to interpret their state constitutions as more protective of liberty than the Federal Constitution."); Thomas G. Saylor, Prophylaxis in Modern State Constitutionalism: New Judicial Federalism and the Acknowledged Prophylactic Rule, 59 N.Y.U. ANN. SURV. AM. L. 283, 286-88 (2003) ("New judicial federalism' generally refers ... to the increased tendency of state courts to interpret state charters as sources of rights independent of the Federal Constitution and interpretations of the United States Supreme Court...."). 
urged that states could and should expand protection for individual rights, ${ }^{128}$ continuing the Warren Court's more liberal civil rights jurisprudence in the face of the Burger Court's retrenchment. ${ }^{129}$ Justice Brennan's suggestion is further articulated by "new federalism", 130 scholars who "share[] the ultimate goal of creating in every state a vigorous, independent body of state constitutional law."131 More broadly, new federalism advocates reinvigorating states' rights and shifting the balance of power back to state governments through judicial and legislative channels. ${ }^{132}$ A recent revival of new federalism has been associated with the Rehnquist Court. ${ }^{133}$ States have embraced new federalism in a number of areas, recognizing broader free speech, criminal procedure, public education, and abortion rights. ${ }^{134}$ Erin Ryan

128. William J. Brennan, Jr., The Bill of Rights and the States, 36 N.Y.U. L. REV. 761, 776-78 (1961); William J. Brennan, Jr., The Bill of Rights and the States: The Revival of State Constitutions as Guardians of Individual Rights, 61 N.Y.U. L. REV. 535, 548, 550 (1986); William J. Brennan, Jr., State Constitutions and the Protection of Individual Rights, 90 HARV. L. REV. 489, 503 (1977).

129. See James A. Gardner, The Failed Discourse of State Constitutionalism, 90 MiCH. L. REV. 761,771 (1991) ("[T]he Burger Court slowed the expansion of constitutionally protected individual rights begun by the Warren Court ...."); Kahn, supra note 126, at 464 ("[Justice Brennan] was eager to preserve the judicial ideals of the $60 \mathrm{~s}$ and $70 \mathrm{~s}$. State constitutionalism represented a kind of forum shopping for liberals."); Stanley Mosk, State Constitutionalism: Both Liberal and Conservative, 63 TEX. L. REV. 1081, 1087 (1985) (recognizing the important role of federal intervention in assisting states to preserve individual rights as per the Warren Court); Daniel B. Rodriguez, State Constitutional Theory and Its Prospects, 28 N.M. L. REV. 271, 271 (1998) (describing Justice Brennan's "strategic effort ... to highlight the value of plumbing the states for individual rights protections in the face of conservative retrenchment"); Robert A. Schapiro, Identity and Interpretation in State Constitutional Law, 84 VA. L. REV. 389, 420 (1998) ("The renewed interest in state constitutions was prompted by the desire to entrench and advance the accomplishments of the Warren Court at a time when the federal judiciary was becoming hostile to the expansion of certain claims of individual rights.").

130. See Gardner, supra note 129, at 771 .

131. Id: see also Paul W. Kahn, Commentary, Interpretation and Authority in State Constitutionalism, 106 HARV. L. REV. 1147, 1147,1159 (1993) (noting that state constitutionalism should be free from U.S. constitutional law); Hans A. Linde, First Things First: Rediscovering the States' Bills of Rights, 9 U. BALT. L. REV. 379, 390 (1980) (noting the tendency for state law arguments to be undermined); Earl M. Maltz, The Political Dynamic of the "New Judicial Federalism," 2 EMERGING IsSUES IN ST. CONST. L. 233, 233-35 (1989) (arguing for state autonomy).

132. See, e.g., Jack M. Balkin \& Sanford Levinson, Understanding the Constitutional Revolution, 87 VA. L. REV. 1045, 1052-53 (2001); Erwin Chemerinsky, The Federalism Revolution, 31 N.M. L. REv. 7, 7-8 (2001); Richard L. Hasen, Congressional Power to Renew the Preclearance Provisions of the Voting Rights Act After Tennessee v. Lane, 66 OHIO ST. L.J. 177, 177 (2005) ("As part of [the new federalism] revolution, the Court has greatly restricted the ability of Congress to pass laws regulating the conduct of the states under its enforcement powers granted in Section Five of the Fourteenth Amendment....."); Jeffrey A. Modisett, Discovering the Impact of the "New Federalism" on State Policy Makers: A State Attorney General's Perspective, 32 IND. L. REV. 141, 141 (1998).

133. See Ryan, supra note 93, at 599-601; Young, supra note 58, at 6.

134. See, e.g., Cruzan v. Dir., 497 U.S. 261, $280-83$ (1990) (recognizing that Missouri is 
notes that critics of the "New Federalism revival" dismiss it also as "an opportunistic political ploy attempting substantive political objectives under the unrelated guise of preserving constitutional federalism." ${ }^{335}$ In other words, according to the Box 1 view, Box 4 arguments, whether new or old, are likewise disingenuous and detrimental.

Federalism arguments pervade the health reform debate. Opportunistic federalism provides a plausible explanation inasmuch as much of the health reform opposition does not concern the allocation of power between states and the federal government. But opportunistic federalism is an overly blunt explanation for the current national dialogue. After considering ACA objections more carefully, it is apparent that opponents loudly, if selectively, do seem to care very deeply about protecting structural values, aside from attacking the merits of ACA or voicing ideological views on health care rights and responsibilities. ${ }^{136}$ Moreover, the constant invocation of federalism rhetoric in the health reform conversation suggests that federalism has greater political salience than opportunistic federalism theories suggest. ${ }^{137}$ Even if some of the rhetoric is empty, incoherent, or inconsistent, nuanced issues of health care policymaking and federalstate relations are now placed "at the center of American political life." ${ }^{138}$ Accordingly, opportunistic federalism theories do not fully account for the rhetorical value of federalism in the current debate.

To test the uncooperative federalism and opportunistic federalism theories, I examine key provisions of ACA that either implicate states or have been the object of states' health reform nullification efforts. The provisions discussed in Part IV include Medicaid expansion, high-risk insurance pools, Exchanges, health insurance market reforms, and the individual health insurance mandate. Following each description, I explain the limits of the operative theories to account for states' resistance to, or acceptance of, those provisions.

\section{Role of States IN Federal HeAlth ReForm}

ACA is staggering in scope and length, addressing everything from employer responsibility to offer health insurance, ${ }^{139}$ prohibition on

entitled to accord stronger protection to preservation of life than federal law by requiring clear and convincing evidence to terminate life support).

135. Ryan, supra note 93 , at 600.

136. See Huq, supra note 28 (noting the concern for "states[] and individual liberty" in the state complaints against the ACA).

137. See id.

138. Bruce Ackerman, A Generation of Betrayal?, 65 FORDHAM L. REV. 1519, 1519 (1997).

139. See Health Care and Reconciliation Act of 2010, Pub. L. No. 111-152, § 1003(a)-(c), 124 
preexisting condition exclusions in health insurance plans, ${ }^{140}$ health care provider reimbursement, ${ }^{141}$ public health demonstration projects, ${ }^{142}$ expansion of federal health care programs, ${ }^{143}$ extension of dependent child coverage, ${ }^{144}$ health information technology, ${ }^{145}$ break time for nursing mothers, ${ }^{146}$ taxes on tanning salon customers, ${ }^{147}$ and restaurant nutrition labeling, ${ }^{148}$ to name just a few.

This Part describes ACA provisions relevant to the role of states in health reform and states' reactions to the new law. My discussion begins with Medicaid, a long-standing cooperative federalism program in which all states participate but to which many are now objecting. Next, I consider states' divergent reactions to two new requests for state cooperation with federal authorities: high-risk insurance pools, which many states have resisted, and health insurance Exchanges, to which most, if not all, states seem amenable. I also consider states' notable lack of objection to a host of new federal health insurance market regulations that broadly preempt state authority and discretion. Finally, I observe that states' loudest objections are directed at the individual health insurance mandate, a new federal requirement that has very little impact on state authority and discretion.

The survey of ACA provisions reveals that state resistance does not follow a principled line or fit a single federalism theory. States balk at

Stat. 1029, 1033; Patient Protection and Affordable Care Act, Pub. L. No. 111-148, sec. 1511, $\S 18$ A, 124 Stat. 119, 252 (2010).

140. See Patient Protection and Affordable Care Act, sec. 1201, § 2704, 124 Stat. at 154-55.

141. See Health Care and Reconciliation Act of $2010 \S 1105$ (a)-(d), 124 Stat. at 1047-49 (requiring Medicare market basket update); id. $\$ 1109(\mathrm{a}), 124$ Stat. at 1051 (allocating payments to qualifying hospitals); id. $\S 1202$ (a)-(b), 124 Stat. at 1052-53 (allocating payments to primary care physicians); Patient Protection and Affordable Care Act $\$ 3401$ (a), 124 Stat. at 480-81 (requiring basket updates for inpatient acute hospitals); id. sec. 3023, $\S 1866 \mathrm{D}, 124$ Stat. at $399-403$ (creating a bundled payment pilot project); id. $\S 3102(\mathrm{~b}), 124$ Stat. at 416-17 (mandating geographic adjustments to physician fee schedules).

142. See Patient Protection and Affordable Care Act $\S 4201(\mathrm{a}), 124$ Stat. at 564 (allocating community transformation grants); id. $\$ 4201(b)(1)$ (providing grants to states, local health departments, and Indian tribes to carry out public health programs); id. $\S 4102(\mathrm{a}), 124$ Stat. at 550 (providing grants for oral health demonstration projects); id. $\S 4206,124$ Stat. at 576-77 (establishing an individual wellness demonstration project); id. $\S 10408$ (a)-(c), 124 Stat. at 977-78 (establishing small employer worksite wellness programs).

143. See Health Care and Reconciliation Act of $2010 \S 1101(\mathrm{a})(1), 124$ Stat. at 1036-37 (closing the Medicare Part D "donut hole"); id. §1201(1), 124 Stat. at 1051 (allocating federal funding for Medicaid expansion); Patient Protection and Affordable Care Act $\$ 2101$ (b) (requiring states to maintain Children's Health Insurance Program ("CHIP") eligibility levels).

144. Patient Protection and Affordable Care Act $\$ 2714,124$ Stat. at 132.

145. Id. sec. $1561, \S 3021,124$ Stat. at 262-64.

146. Id. $\S 4207,124$ Stat. at $577-78$.

147. Id. $\S 10907(\mathrm{~b}), 124$ Stat. at 1020-21.

148. Id. $\S 4205,124$ Stat. at 573-76. 
voluntary programs, yet fail to exercise their exit rights. States walk both sides of the line on new requests for cooperation, at times objecting loudly to federal authorities' requests, and at times willingly assuming the newly assigned responsibility. ${ }^{149}$ States seem to tolerate expansive federal preemption of traditional reserved powers, yet strenuously resist federal attempts to restrict individual rights of their residents. ${ }^{150}$ Despite the inconsistency, when states do object, federalism is the rallying cry. ${ }^{151}$ The health reform debate has given new political salience to the rhetoric, even if not the substance, of federalism.

\section{A. Medicaid Expansion}

Medicaid is a long-standing, classic example of cooperative federalism that relies heavily on states to carry out federal policies. ${ }^{152}$ States have long participated in Medicaid, but several object to ACA's new eligibility rules and administrative burdens on states. Medicaid is a conditional spending program whereby Congress offers federal dollars to states that agree to implement state Medicaid programs. ${ }^{153}$ The federal Medicaid statute outlines broad eligibility, coverage, provider enrollment, and procedural requirements. States that agree to implement programs meeting those requirements receive a percentage-on-the-dollar match from the federal government for every state dollar spent on the approved program. ${ }^{154}$ States also receive federal matching dollars for state spending on certain optional groups of beneficiaries and services. ${ }^{155}$ Financial contribution by both the states and the federal government is the "cornerstone of Medicaid." 156 States are incentivized

149. See supra Part III (discussing two theories as to why states may object or assent to federal authority).

150. See supra notes $9-10$ and accompanying text (noting the concern for individual rights in the states' challenge to the ACA).

151. See supra Part III.B.

152. See, e.g., Rosenbaum, supra note 28 , at 1954.

153. See 42 U.S.C. $\$ 1396$ (2006) (describing federal appropriation of money to the states); Atkins v. Rivera, 477 U.S. 154, 156-57 (1986) (describing Medicaid as a joint federal-state partnership); Schweiker v. Gray Panthers, 453 U.S. 34, 36-37 (1981) (same); Harris v. McRae, 448 U.S. 297, 308 (1980) ("Medicaid . . is a cooperative endeavor in which the Federal Government provides financial assistance to participating States to aid them in furnishing health care to needy persons."); Nicole Huberfeld, Bizarre Love Triangle: The Spending Clause, Section 1983, and Medicaid Entitlements, 42 U.C. DAVIS L. REV. 413, 419-20 (2008) (describing the state-federal relationship under Medicaid); Rose-Ackerman, supra note 68, at 1346; Sara Rosenbaum et al., Public Health Insurance Design for Children: The Evolution from Medicaid to SCHIP, 1 J. HEALTH \& BIOMED. L. 1, 7-8 (2004).

154. See Eleanor D. Kinney, Rule and Policy Making for the Medicaid Program: $A$ Challenge to Federalism, 51 OHIO ST. L.J. 855, 860-61 (1990) (providing a program overview).

155. See id. at 865-67.

156. Harris, 448 U.S. at 308. 
to provide generous public benefits, receiving federal support for every dollar spent, while the federal government shifts a portion of the funding burden to states. ${ }^{157}$

Medicaid is entirely voluntary; states do not have to participate and could refuse federal dollars, establishing their own state indigent health care programs or electing not to provide any medical assistance for lowincome individuals. ${ }^{158}$ Currently, all states have accepted the conditional funding carrot and operate approved state Medicaid plans. ${ }^{159}$ The constitutionality of cooperative federalism arrangements like Medicaid is beyond any serious doubt as states retain the option of simply walking away from the partnership and refusing federal dollars. ${ }^{160}$

ACA expands Medicaid by creating a new, categorically eligible population, and lowering the income threshold for certain currently eligible groups. ${ }^{161}$ Historically, Medicaid provided no coverage for lowincome adults unless they had eligible children or were elderly or disabled. ${ }^{162}$ The new federal law extends Medicaid to all children, parents, and childless adults who are not entitled to Medicare and have family incomes up to $133 \%$ of federal poverty level ("FPL"). ${ }^{163}$ States

157. See Kinney, supra note 154 , at $860-61$.

158. See id. at 860 .

159. See Genevieve Kenney \& Justin Yee, SCHIP at a Crossroads: Experiences to Date and Challenges Ahead, 26 HEALTH AFF. 356, 356 (2007), available at http://content.healthaffairs.org/ content/26/2/356.full.pdf; KAISER COMM'N ON MEDICAID \& THE UNINSURED, MEDICAID: A PRIMER 4 (2009), available at http:/www.kff.org/medicaid/upload/7334-03.pdf. Notably, Arizona did not participate in Medicaid until 1982. See Mem'l Hosp. v. Maricopa Cnty., 415 U.S. 250, 262 n.19 (1974) (noting that Arizona did not participate at the time of that decision).

160. See New York v. United States, 505 U.S. 144, 167-68 (1992) (explaining the constitutional principles of conditional spending); South Dakota v. Dole, 483 U.S. 203, 207-08 (1987) (discussing the limits of federal spending power); Pennhurst State Sch. \& Hosp. v. Halderman, 451 U.S. 1, 17 (1981) ("[O]ur cases have long recognized that Congress may fix the terms on which it shall disburse federal money to the States."); Helvering v. Davis, 301 U.S. 619, 645-46 (1937) (upholding mandatory payroll tax to support Social Security as constitutional use of congressional spending power); Steward Mach. Co. v. Davis, 301 U.S. 548, 590-93 (1937) (discussing the constitutionality of the unemployment compensation law); see also Abbe Gluck, The 10th Amendment Question, Comment to Is the Health Care Law Unconstitutional?, ROOM FOR DEBATE (Mar. 28, 2010, 7:00 PM), http://roomfordebate.blogs.nytimes.com/2010/03/28/is-thehealth-care-law-unconstitutional/ (emphasizing that Medicaid is a voluntary program and that states are free to "drop the program entirely" if they do not wish to expand eligibility).

161. See Rosenbaum, supra note 28 , at 1953.

162. See id. at 1952-53.

163. See Patient Protection and Affordable Care Act, Pub. L. No. 111-148, § 2001(a), 124 Stat. 119, 271-72 (2010); see also Rosenbaum, supra note 28, at 1953 (citing Congressional Budget Office estimates that new income calculation methods will effectively raise the threshold to $138 \%$ of the FPL). Under 2010 standards, a family of three that earns $\$ 24,352.30$ per year meets the $133 \%$ FPL. See CTRS. For MEdiCARE \& MEDiCaID SERVS., U.S. DEP'T OF HEALTH \& HuMAN SERVS., 2010 POVERTY GUIDELnNES, available at https:/www.cms.gov/MedicaidEligibility/downloads/ POV10Combo.pdf. 
may expand their Medicaid programs as early as April 1, 2010, and must cover newly eligible individuals by January $1,2014 .^{164}$ Also, beginning January 1, 2014, Medicaid income eligibility for children expands from the current $100 \%$ FPL to $133 \%$ FPL. ${ }^{165}$ All newly eligible individuals must be guaranteed a benchmark plan that provides essential health benefits, as defined in ACA. ${ }^{166}$ Medicaid currently covers sixty million Americans. ${ }^{167}$ By 2014, sixteen million more people will be eligible. ${ }^{168}$ By $2020,25 \%$ of the U.S. population will be covered by Medicaid, making it the single largest payor of health care services in the country. ${ }^{169}$ The expansion is estimated to cost $\$ 434$ billion just in federal dollars, not to mention state spending. ${ }^{170}$

ACA places much of the funding onus for Medicaid expansion on the federal government. ${ }^{171}$ Under traditional Medicaid, the Federal Medicaid Assistance Percentage that states receive to match their state Medicaid spending varies based on states' relative poverty levels, from at least $50 \%$ up to almost $75 \%$. $^{172}$ Under the new law, the federal government will bear a larger percentage of the cost for newly eligible individuals. For the first three years, 2014 to 2016, the federal government will pay $100 \%$ of the cost for "new eligible" individuals in all states. ${ }^{173}$ Thereafter, the federal percentage phases down gradually, from $95 \%$ in 2017 , to $90 \%$ in 2020 and thereafter. ${ }^{174}$

164. Patient Protection and Affordable Care Act $\S 2001(a)(1)(C), 124$ Stat. at 271.

165. Id. $\$ 2001$ (a)(4), 124 Stat. at 274.

166. Id. \$2001(c)(3), 124 Stat. at 276-77.

167. Stephen A. Somers, Medicaid in 2010: A Year of Transformation, CTR. FOR HEALTH CARE STRATEGIES (Jan. 2010), http://www.chcs.org/usr_doc/President\%27s_Message_-_January_ 2010.pdf; Controlling Costs of Medicaid (Kansas Public Radio broadcast May 10, 2010), available at http://www.kansaspublicradio.org/newsstory.php?itemID=21661.

168. See Rosenbaum, supra note 28, at 1952 (including Medicaid and CHIP); Controlling Costs of Medicaid, supra note 167.

169. See Controlling Costs of Medicaid, supra note 167.

170. Rosenbaum, supra note 28 , at 1952.

171. See JOHN HOLAHAN \& IRENE HEADEN, KaISER COMM'N ON MEdicaid \& THE UNINSURED, MEDICAID COVERAGE AND SPENDING IN HEALTH REFORM: NATIONAL AND STATEBY-STATE RESULTS FOR ADULTS AT OR BELOW 133\% FPL 2 (2010), available at http://www.kff.org/healthreform/upload/Medicaid-Coverage-and-Spending-in-Health-Reform-

National-and-State-By-State-Results-for-Adults-at-or-Below-133-FPL.pdf (estimating that $95 \%$ of new spending will be by the federal government).

172. See Federal Matching Shares for Medicaid, the Children's Health Insurance Program, and Aid to Needy Aged, Blind, or Disabled Persons, 74 Fed. Reg. 62,315, 62,315 \& 62,316 tbl. (Nov. 27, 2009).

173. Health Care and Reconciliation Act of 2010, Pub. L. No. 111-152, § 1201(1), 124 Stat. 1029, 1051; Patient Protection and Affordable Care Act, Pub. L. No. 111-148, § 2001(a)(3)(B), 124 Stat. 119, 272 (2010).

174. See Rosenbaum, supra note 28, at 1954; MARTHA HEBERLEIN ET AL., KAISER COMM'N

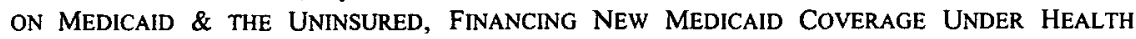
REFORM: THE ROLE OF THE FEDERAL GOVERNMENT AND STATES 2 (2010), available at 
States also face additional administrative requirements under ACA to coordinate Medicaid enrollment with other government and private health insurance plans. A new federal condition of participation for Medicaid requires states to establish Internet websites for patients to enroll in Medicaid and the state Children's Health Insurance Program ("CHIP"). ${ }^{175}$ If individuals are deemed ineligible for Medicaid or CHIP, the website must screen for eligibility for premium assistance and Exchange enrollment, using the same application form. ${ }^{176}$ The federal government is responsible for creating the streamlined application form, ${ }^{177}$ but states may develop alternative forms, as long as they meet federal requirements. ${ }^{178}$ With the aim of enlisting more providers to treat the newly eligible population, ACA raises the Medicaid primary care physician reimbursement rate to Medicare levels. ${ }^{179}$ The federal government will bear the full cost of that payment increase for the first two years, ${ }^{180}$ but there is no promise of federal funding thereafter.

Expansion of the Medicaid program is one of the central complaints in the Florida lawsuit, which characterizes the legislation as "an unprecedented encroachment on the sovereignty of the states." 181 The suit acknowledges that Medicaid began as a voluntary partnership between states and the federal government in which states could freely participate or decline. ${ }^{182}$ After more than four decades of Medicaid's existence, the Plaintiff States assert, the program has become "customary and necessary for citizens throughout the United States."183 Accordingly, the Plaintiff States claim that they no longer have any real choice about participation, turning the program into "a compulsory topdown federal program" that exceeds federal enumerated powers and

http:/www.kff.org/healthreform/upload/8072.pdf.

175. See Patient Protection and Affordable Care Act, sec. 2201, § 1943(a)-(b), 124 Stat. at 289-91. CHIP is another cooperative federalism program, offering states federal block grants to extend state health plans to children who otherwise exceed the income eligibility requirements for Medicaid. See 42 U.S.C. $\S \S 1397 \mathrm{aa}-1397 \mathrm{jj}$ (2006) (establishing the CHIP program). States also must maintain current income eligibility levels for children in CHIP through September 30, 2019 , and receive a $23 \%$ increase in the federal CHIP match. See Patient Protection and Affordable Care Act $\$ 2101(a), 124$ Stat. at 286.

176. See Patient Protection and Affordable Care Act, sec. 2201, § 1943(b)(1), 124 Stat. at 28990.

177. Id. $\S 1413(\mathrm{~b})(1)(\mathrm{A}), 124$ Stat. at $233-34$.

178. Id. $\$ 1413(\mathrm{~b})(1)(\mathrm{B}), 124$ Stat. at 234 .

179. See Health Care and Reconciliation Act of 2010, Pub. L. No. 111-152, § 1202(a), 124 Stat. 1029, 1052-53.

180. Id. $\S 1202$ (b), 124 Stat. at 1053.

181. Florida Complaint, supra note 18 , at 4.

182. See id. at 9.

183. Id. at 5; see Rosenbaum, supra note 28, at 1954 (summarizing and critiquing arguments of states challenging the ACA). 
intrudes on states' reserved powers. ${ }^{184}$ Judge Vinson, while accepting the states' challenge to the individual mandate, roundly rejected their challenge to Medicaid expansion, noting "that state participation in the Medicaid program under [ACA] is-as it always has beenvoluntary." 185

In addition to lawsuits, state objection to Medicaid expansion has taken other forms. Legislation proposed in New Hampshire would have prohibited expansion of the state Medicaid program unless the state legislature approved, or the federal government funded the expansion. ${ }^{186}$ Four other states are considering similar bills resisting additional financial burdens on states as a result of federal health care reforms. ${ }^{187}$ In debates over the U.S. Senate health reform bill, Ben Nelson of Nebraska agreed to sign the bill only in exchange for a special provision providing $100 \%$ federal funding for Medicaid expansion exclusively for his state. ${ }^{188}$ Although the so-called "Cornhusker compromise" was struck from the final law, it evidences state resistance to cooperatively funding the federal program. ${ }^{189}$ Several months after ACA's enactment, Congress voted, in an emergency session, to provide additional federal Medicaid funding for states through June $2011,{ }^{190}$ but with no promise of additional funding for ACA's Medicaid expansion.

The two plausible federalism theories fall short of explaining state resistance to Medicaid expansion. For much of the Medicaid program's history, it has fit the cooperative federalism model. In the current climate, uncooperative federalism is descriptively accurate inasmuch as states are balking at the new burdens. Given the deep level of state integration with federal authorities in Medicaid administration, ${ }^{191}$ and the federal government's dependence on states to operate the program, uncooperative federalism predicts that states should wield considerable power. $^{192}$

184. Florida Complaint, supra note 18 , at 5 .

185. Florida Summary Judgment, supra note 30, at *19-20.

186. See Cauchi, supra note 4 , at tbl. 1 .

187. See id. (listing Arizona, Illinois, Iowa, and Michigan).

188. See Lisa Mascaro, Health Care Compromise Gives Sweet Medicaid Deal to Nebraska, LAS VEGAS SUN (Dec. 20, 2009, 9:22 PM), http://www.lasvegassun.com/news/2009/dec/20/reidcompromise-gives-sweet-medicaid-deal-nebraska/.

189. See, e.g., id. (discussing Nebraska's resistance to the ACA).

190. See David Herszenhorn, Senate Vote Clears Way for Billions in Aid to States and School Districts, N.Y. Times, Aug. 5, 2010, at A14; Carl Hulse, House Passes Bill to Aid States and Public Schools, N.Y. TIMES, Aug. 11, 2010, at A14; Lori Montgomery \& Nick Anderson, Obama Signs $\$ 26$ Billion Jobs Bill, WASH. POST, Aug. 11, 2010, at A12.

191. Bulman-Pozen \& Gerken, supra note 43, at 1268-70 (describing the theory of integration).

192. See id. at 1266; Rosenbaum, supra note 28 , at 1953 (noting that a jointly funded Medicaid program allows the federal government to defray a portion of the costs onto states). 
Yet states have failed to protest forcefully or productively, other than filing lawsuits on dubious grounds. ${ }^{193}$ Objecting states have not suggested any preferable alternative policy, other than demanding increased federal funds. ${ }^{194}$ No state has urged repeal of Medicaid or seriously suggested that it will opt-out of Medicaid to protest the new coverage and administrative requirements. Indeed, the essence of the allegation in the Florida lawsuit was that states, as a practical matter, simply cannot opt-out. ${ }^{195}$ That dynamic should provoke strong dissent and productive dialogue. ${ }^{196}$ If states no longer have a real choice, the federal-state partnership becomes more coercive than cooperative, ${ }^{197}$ nudging close to the commandeering line. ${ }^{198}$ Bulman-Pozen and Gerken predict that if "states are so starved for federal funding that they cannot afford to turn down a federal invitation to join a regulatory scheme" and are "forced to implement a program they find distasteful,"199 that "should push them to engage in variants of uncooperative federalism."200 Bulman-Pozen and Gerken recognize that conditional spending programs can cut both ways, depending on how desperate states are for federal dollars. ${ }^{201}$ In the Medicaid context, states' dependence on federal funds has rallied their objection but also silenced their effective dissent. As the issue stands, the federal government is not compelled to respond to states or consider other ways of extending health insurance coverage to low-income individuals.

Opportunistic federalism is also inapt to the Medicaid debate because objecting states do, in fact, seem to care very much about structural allocation of power. Opponents cite concerns about state power, autonomy, and fiscal and administrative burdens-classic federalism tensions. ${ }^{202}$ The Florida lawsuit alleges that Congress exceeded its spending power and intruded on Tenth Amendment

193. See Massachusetts v. Mellon, 262 U.S. 447, 485-86 (1923) (holding that states have no standing to challenge the constitutionality of a federal law).

194. See supra notes $188-89$ and accompanying text (describing the Nebraska compromise).

195. But see Florida Summary Judgment, supra note 30, at *20 (Judge Vinson concluding that the states' assertion that "their participation is involuntary, and that they cannot exit the program . . . is contrary to the judicial findings in numerous other Medicaid cases").

196. See Florida Complaint, supra note 18, at 10-11.

197. See South Dakota v. Dole, 483 U.S. 203, 211 (1987).

198. See Florida Complaint, supra note 18, at 13 ("[Florida's Agency for Health Care Administration ("AHCA")] and the other Florida agencies will be rendered arms of the federal government, and AHCA employees will be conscripted and forced to administer what is now essentially a federal Medicaid program ....").

199. Bulman-Pozen \& Gerken, supra note 43 , at 1300

200. Id.

201. See id. at 1300-01 (noting that state dissent, stemming from conditional spending programs, may depend on the amount of power Congress has asserted under the doctrine).

202. See Florida Complaint, supra note 18 , at $4,5,14-15$ 
reserved powers by effectively commandeering states to expand their Medicaid programs. ${ }^{203}$ States do not object, in the main, to a government health care program for the indigent or a cooperative federal-state approach to covering those individuals. They, instead, suggest that the cooperative, voluntary nature of the program has been fundamentally altered by ACA's onerous new requirements. ${ }^{204}$ Their concerns, then, are precisely about allocation of power within the federalist system and not simply proxies for substantive policy objections.

\section{B. High-Risk Pools}

In addition to expanding the long-standing Medicaid cooperative federalism arrangement, ACA seeks to enlist states in new cooperative programs. The first new program involves establishing temporary highrisk insurance pools, dubbed the Pre-Existing Condition Insurance Program. $^{205}$ ACA requires the U.S. Secretary of Health and Human Services, within ninety days of the law's enactment, to establish highrisk health insurance pools. ${ }^{206}$ As an alternative to establishing a federal high-risk pool, the statute allows the secretary to contract with states or nonprofit organizations to carry out the requirement. ${ }^{207}$ At least twenty states elected not to cooperate with the federal government in establishing high-risk insurance pools, including strong vocal objections from some states' lawmakers. ${ }^{208}$

The temporary high-risk pools are intended to operate as stop-gaps until other provisions, namely the ban on pre-existing condition exclusions, guaranteed issue and renewability, ${ }^{209}$ and the Exchanges, ${ }^{210}$ take effect on January 1, 2014, on which date the high-risk pools will

203. See id. at 16.

204. See id. at 14-15.

205. See Patient Protection and Affordable Care Act, Pub. L. No. 111-148, §1101(a), 124 Stat. $119,141(2010)$.

206. Id.

207. Id. $\$ 1101(\mathrm{~b})$.

208. See Brown, supra note 31 (discussing Georgia's decision to object to the insurance plans); Christy Hoppe, Gov. Rick Perry Says Texas Won't Run High-Risk Insurance Pool, DaLl. MoRNiNG NEws (May 1, 2010, 12:00 AM CDT), http://www.dallasnews.com/sharedcontent/dws/news/ texassouthwest/stories/DN-texhealthcare_01 nat.ART.State.Edition2.139685.html; Julian Pecquet, GOP Governors Opting Out of Health Reform Pool for High-Risk Uninsured, THE HILL (May 1, 2010, 12:17 PM ET), http://thehill.com/business-a-lobbying/95443-gop-govemors-opting-out-ofhealth-reform-risk-pool; Some Republican States Opting Out of High Risk Health Insurance Pools, KAISER HEALTH NEwS (May 2, 2010), http://www.kaiserhealthnews.org/Daily-Reports/ 2010/May/01/high-risk-health-insurance-pools-hhs.aspx (summarizing news reports from around the country which discuss states' objections to the ACA's insurance provisions).

209. See Patient Protection and Affordable Care Act, sec. 1201, $\S \S 2703-04,124$ Stat. at 154 56.

210. Id. §1311(b), 124 Stat. at 173-74. 
expire. $^{211}$ ACA requires qualified high-risk pools to provide health insurance coverage without pre-existing condition exclusions and comply with specified premium and out-of-pocket limits. ${ }^{212}$ United $^{-}$ States citizens with pre-existing conditions who have been uninsured for six months are eligible for coverage through the temporary pools. ${ }^{213}$

Under ACA, the secretary may establish the high-risk pools directly or through contracts with eligible entities, including states or nonprofit entities. $^{214}$ States enter contracts with the secretary and receive federal funding to establish and administer the pools. ACA's requirements expressly preempt any state laws relating to qualified high-risk pools under the statute. ${ }^{215}$ Accordingly, states that already operate pre-ACA high-risk pools could bring their existing programs into compliance with ACA or operate two separate programs side-by-side. ${ }^{216}$ Alternatively, if states decline to operate high-risk health insurance pools, the federal government will establish and operate the pools. Congress appropriated $\$ 5$ billion for the purpose, ${ }^{217}$ with state allotments ranging from $\$ 8$ million to $\$ 761$ million. ${ }^{218}$

Thirty states and the District of Columbia responded that they would accept the federal funding and establish state high-risk pools. ${ }^{219}$ Twenty states refused the funding, leaving the task to the federal government. $^{220}$ States that refused expressed concern about inadequate funding and unclear guidelines, fearing that the task would ultimately devolve to an unfunded mandate. ${ }^{221}$ The cooperative and uncooperative states fell in roughly around party lines. ${ }^{222}$ States with Democratic

211. Id. $\S 1101(\mathrm{a}), 124$ Stat, at 141.

212. Id. \$1101(c), 124 Stat. at 141-42.

213. Id. $\$ 1101(\mathrm{~d}), 124$ Stat. at 142 .

214. Id. $\$ 1101(\mathrm{~b})(1)-(2), 124$ Stat. at 142 .

215. Id. $\$ 1101(\mathrm{~g})(5), 124$ Stat. at 143.

216. See News Release, U.S. Dep't of Health \& Human Servs., Sebelius Continues Work to Implement Health Reform, Announces First Steps to Establish Temporary High Risk Pool Program (Apr. 2, 2010), http://www.hhs.gov/news/press/2010pres/04/20100402b.html.

217. Patient Protection and Affordable Care Act $\$ 1101(\mathrm{~g})(1), 124$ Stat. at 143.

218. Robert Pear, States Decide on Running New Pools for Insurance, N.Y. TIMES, Apr. 30, 2010 , at A15.

219. States That Intend to Operate Their Own High Risk Pools, NAT'L ASS'N OF INS. COMM'RS, http://naic.org/documents/index_health_reform_high_risk_pools_list_of_states.pdf.

220. See Robert Pear, Insurance Pools Readied in Some States, N.Y. TIMES, June 27, 2010, at A17.

221. See Pear, supra note 218; see also Haberkorn, supra note 32 ("[S]tates are concerned that the $\$ 5$ billion HHS has to implement the program will quickly run dry, leaving cash-strapped states with another tab."); Hoppe, supra note 208 ("As we've seen in federal education and stimulus programs, the administration is again asking states to commit to a program without knowing the rules of engagement."' (quoting Governor Rick Perry of Texas)).

222. See Haberkorn, supra note 32 (noting Republican officials objecting to the ACA); Hoppe, supra note 208 (recognizing that of fifteen states refusing to create the temporary insurance pools, 
governors generally agreed to operate the high-risk pools, while states with Republican governors generally refused. But there were notable exceptions. ${ }^{223}$ Republican Governor Arnold Schwarzenegger chose to accept $\$ 761$ million annual federal funds rather than let the federal government run California's high-risk pool. ${ }^{224}$ But Wyoming's Democratic Governor Dave Freudenthal turned down $\$ 8$ million, expressing concern that the federal funding would be insufficient. ${ }^{225}$ The political rhetoric is also mixed, with some suggesting that giving states the option to operate their own pools was intended to appease Republican concerns about expansion of federal power, ${ }^{226}$ and others suggesting that the state high-risk pools are "'the first step in the recently enacted federal takeover of the United States health care system.,",227

As one of the first ACA provisions to take effect, state reaction to the high-risk pools is ripe for consideration under the working federalism theories. States that lined up as supportive allies to establish state high-risk pools exemplify the cooperative federalism model. Those states will receive federal grants in exchange for lending their administrative capacity and expertise to the health reform effort. But states that refused federal dollars, thereby allowing the federal government to operate high-risk pools in their states, defy conventional theories, especially if they are concerned about ceding power and autonomy to the federal government. The mostly Republican state governors who are unwilling to cooperate in implementing high-risk pools also generally oppose federal health reform and expansion of federal power to regulate health care. ${ }^{228}$ Yet they decline the opportunity to retain state regulatory power, receive federal funding, and establish their own state high-risk pools. The preference for a national response is all the more curious considering that thirty-five states, including several

many had Republican governors); Some Republican States Opting Out of High Risk Health Insurance Pools, supra note 208 (listing several Republican states who have chosen to opt-out of the high-risk pools).

223. See Pecquet, supra note 208 (noting that five Republican states have opted to run their own high-risk pools).

224. Pear, supra note 218 (" The federal government has the right to force you into having a health care plan." (quoting Governor Amold Schwarzenegger of California)).

225. Id.

226. See Noam N. Levey, States Resist Creating Pools to Help People Denied Health Insurance, L.A. TIMES, May 1, 2010, http://articles.latimes.com/2010/may/01/nation/la-nahealthcare-20100501.

227. See Pear, supra note 218 (quoting Georgia Insurance Commissioner and Republican gubernatorial candidate John W. Oxendine).

228. See Levey, supra note 226. 
of the objecting states, already operate their own high-risk pools to address similar concerns. ${ }^{229}$

From an uncooperative federalism perspective, states' recalcitrance makes some degree of sense. States that decline to operate high-risk pools are using their power as potential servants to decline federal dollars and refuse to lend a hand. If the federal government depends on states to establish high-risk pools, the secretary may face considerable administrative challenges establishing and operating high-risk pools in the twenty states that have opted out. That should create a climate in which the federal government is compelled to listen closely to dissenting states' concerns and respond accordingly. ${ }^{230}$ But if the federal government can just as easily operate the high-risk pools on its own or through contracts with nonprofit organizations, states' refusals may have little impact.

The uncooperative federalism model further suggests that states command power deriving from their integration with federal authorities. ${ }^{231}$ Health insurance regulation is deeply embedded in state governance. States have a long history, since 1976, of operating highrisk pools and the involved tasks of designating eligibility requirements, benefit packages, beneficiary cost sharing, and provider reimbursement rates. ${ }^{232}$ Any federal high-risk insurance pools would necessarily engage with and draw on state expertise and infrastructure. ${ }^{233}$ Thus, states may hold considerable power deriving from their experience in the area, even if the federal government does not depend on them financially to implement the high-risk pools.

If the uncooperative federalism theory is accurate, we should expect states to use their power as potential servants. But, so far, that has not been the case. States that have declined to establish state-based high-risk pools offer no policy alternative or purposeful dialogue. It seems that those states can simply decline federal dollars and leave the secretary to figure out how to comply with the ACA's requirement, offering no comment on the merits of the federal law. ${ }^{234}$ As long as the federal

229. See Pear, supra note 220 (noting that states, including Alabama, Minnesota, and Texas, have existing high-risk pools but will allow the federal government to run the new ACA high-risk pools in their borders). Alabama and Texas are named plaintiffs on the Florida lawsuit. See Florida Complaint, supra note 18 , at 3.

230. See Bulman-Pozen \& Gerken, supra note 43, at 1266.

231. See id. at 1268-69.

232. See TANYa SChWARTZ, Kaiser COMM'N ON MEdiCAid \& the UNINSUREd, State HighRISK POOLS: AN OVERVIEW 1 (2010), available at http://www.kff.org/uninsured/upload/8041 .pdf.

233. See Jennings \& Hayes, supra note 32 , at 2245.

234. See Bulman-Pozen \& Gerken, supra note 43, at 1295-97 (noting that the commandeering principle may lead states to engage in this type of dissent). 
government can establish and maintain twenty state high-risk insurance pools, the states' refusals have little policy-forcing power. The dynamic, instead, comports with Hills's functional theory (Box 3$)^{235}$ as states are exercising their "entitlement" to withhold state regulatory processes from the federal government unless freely negotiated contractual exchanges are entered. ${ }^{236}$

At first pass, state refusals to establish high-risk insurance pools appear motivated by earnest, structural concerns, similar to their concerns about Medicaid expansion. The fiscal and administrative burdens, lack of clear guidance, and very short, ninety-day timeframe for establishing the high-risk pools gives credence to states' objections. On closer examination, however, the objections to state-based high-risk pools ring untrue if states earnestly value autonomy and sovereign power, suggesting that opportunistic federalism may be at work. Just as conservative Justices underplayed federalism concerns in striking down California's medical marijuana law, ${ }^{237}$ resisting states gloss over the deep state autonomy implications of allowing federal authorities to operate high-risk pools in their states. Federalism values are cast aside in pursuit of other objectives, perhaps with the overarching goal of undermining the entire legislation, piece by piece, as the opportunistic federalism theory suggests. That characterization seems all the more apt when compared to states' conspicuous non-objection to similar cooperative arrangements under ACA, namely health insurance Exchanges, considered next.

\section{Exchanges}

ACA also seeks to enlist state cooperation for new health insurance marketplaces, or Exchanges. So far, states have not voiced strong objections to the particularly onerous demands related to establishing state-operated health insurance Exchanges by $2014 .^{238}$ In contrast to the high-risk pools - the responsibility for which is assigned first to the federal government - which may then contract with states, responsibility

235. See supra notes $52-54$ and accompanying text.

236. See Hills, State Autonomy, supra note 52, at 823 (identifying states' “New York entitlement," or property rule of state regulatory machinery).

237. See Gonzales v. Raich, 545 U.S. 1, $19 \&$ n.29 (2005) (holding that Congress has the authority, pursuant to the Commerce Clause, to regulate local cultivation of marijuana despite a state law allowing intrastate use and production for medical purposes). Erin Ryan points to the Court's decision in Gonzales as an example of judicial opportunistic federalism. See Ryan, supra note 93 , at $600-01$.

238. But see Florida Complaint, supra note 18 , at 16 ("[B]y requiring [states] to establish health insurance exchanges, [ACA] deprives them of their sovereignty and their right to a republican form of government ...."). 
for the Exchanges is assigned first to states, with the federal government as a backstop, should states fail to comply.

Health insurance Exchanges are ACA's attempt to address historical flaws in the individual and small-group health insurance markets. ${ }^{239}$ Lacking the group purchasing power and risk-pooling advantages of group coverage, individuals, small employers, and other groups struggle to obtain affordable private health insurance on the open market. Exchanges are intended to facilitate the availability, choice, and purchase of health insurance for those consumers. ${ }^{240}$ Exchanges centralize information, allowing consumers to compare plans, and facilitate use of tax credits or other subsidies to purchase health insurance. ${ }^{241}$ Currently, three states, including Massachusetts, as part of its comprehensive health reform in $2006,{ }^{242}$ voluntarily operate statebased Exchanges. ${ }^{243}$

Both the House and Senate versions of the federal health reform bill included Exchanges. ${ }^{244}$ But they differed in assigning primary responsibility to the federal or state governments. The House Bill would have created a National Health Insurance Exchange but would have allowed states to opt-in and operate state-based Exchanges if they demonstrated capacity to meet the federal requirements. ${ }^{245}$ The Senate Bill provided for state-based Exchanges, operated by state authorities or nonprofit organizations. ${ }^{246}$

The Reconciliation Bill passed by Congress and signed into law by the President took the Senate's approach. By January 1, 2014, each state must establish American Health Benefit Exchanges and Small Business Health Options Program Exchanges through which individuals and small

239. See Jon Kingsdale, Health Insurance Exchanges-Key Link in a Better-Value Chain, 362 NEW ENG. J. MED. 2147, 2149 (2010) (noting that the ACA would be able to provide exchanges on a national level, which is something that small employers have never been able to do).

240. See Jost, supra note 77, at 53; Kingsdale, supra note 239, at 2149; Amy Lischko, Establishing a State-Level Exchange 8 (Mar. 15, 2010) (unpublished manuscript), http://www.nga.org/Files/pdf/1003HEALTHSUMMITEXCHANGE.PDF.

241. Jost, supra note 77, at 53; Lischko, supra note 240 , at 8 .

242. See Elizabeth A. Weeks, Failure to Connect: The Massachusetts Plan for Individual Health Insurance, 55 U. KAN. L. REV. 1283, 1283, 1290-91 (2007) (describing the Massachusetts health care reform, including the "Connector," that state's exchange).

243. Lischko, supra note 240, at 11-13 (describing exchanges in Massachusetts, Washington, and Utah).

244. See Kaiser family Found., Side-By-Side Comparison of Major Health Care REFORM PROPOSALS 1 (2009), available at http://www.kff.org/healthreform/upload/healthreform sbs_full.pdf.

245. See America's Affordable Health Choices Act of 2009, H.R. 3200, 111th Cong. $\S 208$ (a)(b) (noting the requirements states must meet in order to operate their own exchanges).

246. See Affordable Health Choices Act, S. 1679, 111 th Cong. $\S \S 3105(a), 3106(e)(1)-(2)$ (2009). 
businesses with up to one hundred employees can purchase qualified coverage. ${ }^{247}$ Only U.S. citizens and legal immigrants who are not incarcerated can purchase through the Exchanges. ${ }^{248}$ The Exchanges can be established by a governmental agency or nonprofit entity in each state. ${ }^{249}$ States may also form regional Exchanges in which two or more states can enter into a health care compact. ${ }^{250}$ The federal government will provide funding to states to establish Exchanges within one year of the law's enactment, until January $1,2015 .^{251}$

The federal government retains authority to establish the certification criteria for the state-based Exchanges, while states are responsible for the actual certification of plans and administration of the Exchanges. ${ }^{252}$ The U.S. Secretary of Health and Human Services will establish the criteria for certification of insurance plans as "qualified health plans." ${ }^{\text {253 }}$ States are responsible for rating each health plan offered in an Exchange in accordance with federal standards and certifying health plans as "qualified health plans." 254 Plans that fail to qualify may not be offered on the Exchanges.

The federal statute includes a detailed "essential health benefits package, ${ }^{, 255}$ which must be included in plans sold in the Exchanges. ${ }^{256}$ Essential health benefits at least include ambulatory patient services, emergency services, hospitalization, maternity and newborn care, mental health and substance use disorder services, prescription drugs, rehabilitative and habilitative services and devices, laboratory services, preventative and wellness services, chronic disease management, and pediatric services including oral and vision care. ${ }^{257}$ States may require additional health benefits but must defray the costs of additional coverage through payments directly to patients or insurers. ${ }^{258}$ As an alternative to enrolling certain low-income individuals in the Exchanges,

247. See Patient Protection and Affordable Care Act, Pub. L. No. 111-148, § 1311(b)(1), 124 Stat. 119, 173 (2010). For the first two years, states can limit Exchange participation to employers of fifty or fewer employees. Id. $\$ 1304$ (b)(3); Planning and Establishment of State-Level Exchanges Under Title I of the Patient Protection and Affordable Care Act, 75 Fed. Reg. 45584, 45587, 45589 (Aug. 3, 2010) (to be codified at 45 C.F.R. pt. 170)

248. See Patient Protection and Affordable Care Act $\S 1312(f)(1)(A)-(B), 124$ Stat. at 184.

249. Id. $\S 1311(\mathrm{~d})(1), 124$ Stat. at 176.

250. See id. $\S 1333$ (a), 124 Stat. at 206.

251. Id. $\S 1311(\mathrm{a})(4)(\mathrm{B}), 124$ Stat. at 173.

252. See id. $\S 1321(\mathrm{a})-(\mathrm{b}), 124$ Stat. at 186.

253. Id. $\S 1321(\mathrm{a})(1)(\mathrm{B})$.

254. See id. $\S 1311$ (d)(4)(A), (D), 124 Stat. at 176.

255. Id. $\S 1302(\mathrm{a}), 124$ Stat. at 163.

256. See id. $\S 1302$ (b), 124 Stat. at 163-65.

257. See id.

258. See id. $\S 1311$ (d)(3)(B)(i)-(ii), 124 Stat. at 176. 
states may establish "basic health program[s]" for non-elderly, nonMedicaid-qualified individuals. ${ }^{259}$

ACA also requires state Exchanges to comply with various administrative requirements, defined by the secretary, including marketing limitations, sufficient choice of providers, standardized plan information and enrollment forms, and quality improvement strategies. $^{260}$ States must establish an Internet portal for providing Exchange information, a rating system, and other quality data control systems. ${ }^{261}$ States must also provide a toll-free telephone hotline to respond to requests for assistance. ${ }^{262}$ In addition, states must establish procedures for enrolling individuals and determining eligibility for tax credits. $^{263}$ When individuals submit an application to an Exchange, states will be required to inform them of Medicaid and CHIP eligibility requirements, screen for eligibility, and enroll those individuals in the appropriate program, if any. ${ }^{264}$ States also must certify to the federal government when an individual is exempt from the individual mandate to purchase health insurance. ${ }^{265}$ States are authorized to contract with non-governmental entities to carry out Exchange-related administrative responsibilities. ${ }^{266}$ If states fail to establish Exchanges the federal government will step in, administering them directly or by contracting with a nonprofit entity in the state. ${ }^{267}$

As described even briefly, it is apparent that the Exchanges impose significant financial, administrative, and enforcement burdens on states. According to one estimate, the initial Exchange start-up costs will be $\$ 4.4$ billion in the pre-implementation years, and cumulative administrative costs will be $\$ 37.7$ billion. ${ }^{268}$ State-operated Exchanges rely on states' expertise and experience in regulating commercial health

259. See id. $\S 1331(\mathrm{a})(1), 124$ Stat. at 199.

260. Id. $\$ 1311(\mathrm{c})(1)(\mathrm{A})-(\mathrm{B}),(\mathrm{E})-(\mathrm{F}), 124$ Stat. at 174.

261. See generally id. $\$ 1311$ (d)(4), 124 Stat. at 176-77 (listing the minimum quality functions an Exchange must provide).

262. Id. $\$ 1311(\mathrm{~d})(4)(\mathrm{B}), 124$ Stat. at 176.

263. Id. $\$ 131 \mathrm{l}(\mathrm{d})(4)(\mathrm{G}), 124$ Stat. at 177 (requiring states to establish and maintain an electronic "calculator to determine the actual cost of coverage").

264. Id. $\S 1311(\mathrm{~d})(4)(\mathrm{F})$.

265. Id. $\S 1311(\mathrm{~d})(4)(\mathrm{H})$.

266. See id. $\S 1311(\mathrm{f})(3)(\mathrm{A})-(\mathrm{B}), 124$ Stat. at 179 (listing eligible entities with which a state may contract).

267. Id. $\S 1321$ (c)(1), 124 Stat. at 186 (requiring the secretary to determine by January 1,2013 , whether states will have Exchanges in place by the January 1, 2014 deadline).

268. See Andrea M. Sisko et al., National Health Spending Projections: The Estimated Impact of Reform Through 2019, 29 HEALTH AFF. 1933, 1940 (2010), available at http://content.healthaffairs.org/content/29/10/1933.full.pdf ("[T]he largest new role for state oversight is the creation and operation of the health insurance exchanges."). 
insurance. ${ }^{269}$ States retain some flexibility in operation and enforcement of the Exchanges and related requirements. ${ }^{270}$ The statute's provision of federal funding to states and option of federal management ensure that Exchanges do not run awry of the anti-commandeering doctrine, ${ }^{271}$ at least for the first few years. But federal funding ceases in $2015 .^{272}$ The statute also contains a nominal opt-out provision. ${ }^{273}$ By contrast to the high-risk pools, so far, only two states have indicated that they will decline to cooperate. ${ }^{274}$

Like state-based high-risk insurance pools, state-based Exchanges represent a concession to Republican lawmakers who resisted increasing federal authority and favored retention of state control over health care reform. ${ }^{275}$ The provisions operate from different baselines and employ different cooperative federalism mechanisms. The high-risk pools operate from the baseline that the federal government will operate them, but the secretary can exercise conditional spending power, in the form of grants, to engage state cooperation. The Exchanges operate from the baseline that states are primarily responsible, but the secretary can exercise conditional preemption by taking over nonexistent or noncompliant state-based Exchanges. ${ }^{276}$ Despite their similarities, the two provisions have drawn divergent responses from states.

Neither of the operative theories accounts for states' non-objection to state Exchanges. The lack of dissent is notable, especially by contrast to the strong resistance to state high-risk pools. The uncooperative federalism model suggests that the soft opt-in-high-risk pools-would

269. See Jost, supra note 77, at 56.

270. See generally Patient Protection and Affordable Care Act $\S \S 1321,1332,124$ Stat. at 18687, 203-06 (allowing for state flexibility and innovation of the general provisions of the ACA).

271. See supra notes 71-72 and accompanying text.

272. See Patient Protection and Affordable Care Act $\S 1311$ (a)(4)(B), 124 Stat. at 173.

273. See id. $\S 1321$ (c), 124 Stat. at 186-87.

274. Minnesota and Alaska have refused federal funds to establish Exchanges. See Exec. Order No. 10-12, 35 Minn. Reg. 394 (2010); Sarah Kliff \& Jennifer Haberkorn, Alaska Turns Down Fed Funds in Protest, POLITICO (Oct. 1, 2010, 6:09 AM), http://www.politico.com/ politicopulse/1010/politicopulse345.html.

275. See Lori Robertson, Still on the Table?, FACTCHECK.ORG (Feb. 22, 2010, 3:00 PM), http://www.factcheck.org/2010/02/still-on-the-table/index.html (noting that Republican plans for health care envisioned more state control); Paul Waldman, Republican Governors Push Federalization of Health Insurance, THE AM. PROSPECT (May 4, 2010, 3:45 PM), http:/www.prospect.org/csnc/blogs/tapped_archive?month=05\&year=2010\&base name=republica $\mathrm{n}$ govemors push fede (noting Republican outcry of the health care law and suggesting that Republicans allow the federal government to set up Exchanges in Republican states in order to avoid any blame if plans go awry).

276. See Patient Protection and Affordable Care Act $\S 1321(\mathrm{c})-(\mathrm{e}), 124$ Stat. at 186-87 (discussing the federal government's role where states do not establish Exchanges, or, in the alternative, require assistance in the implementation of the federal requirements). 
trigger milder reaction than the hard opt-out-Exchanges. ${ }^{277}$ If states can easily, without consequences, walk away from a federal program with which they disagree, "they may not have much incentive to devote the resources needed to mount an effective challenge to federal policy."278 Yet, twenty states spurned the secretary's invitation to establish state high-risk pools while, so far, ${ }^{279}$ only two have expressed unwillingness to establish an Exchange, ${ }^{280}$ precisely the opposite of uncooperative federalism's prediction.

States' incongruous response to two similar cooperative federalism arrangements under ACA comports with opportunistic federalism. Health reform opponents invoke federalism arguments when it is to their advantage but look past those concerns when other policy objectives predominate. $^{281}$ At this time, it is hard to say whether states' nonobjection to the Exchanges evidences earnest preference for state autonomy or opportunistic use of federalism arguments to advance other objectives. If states are earnestly concerned about retaining state power, it seems that they should prefer state implementation of both high-risk pools and Exchanges. Although a significant number of states have opted for federal high-risk pools, most seem to prefer state-based Exchanges. ${ }^{282}$ Indeed, during congressional debates, state-based Exchanges won over a national Exchange, ${ }^{283}$ in part, because of concerns about the expansion of federal power. If states maintain their support for state-based Exchanges, there may be nothing opportunistic about it. Lack of opposition may demonstrate the real salience of structural values, not merely as a rhetorical device but as a substantive policy preference.

277. See Bulman-Pozen \& Gerken, supra note 43, at 1291 ("Forcing state officials to participate in a federal scheme they oppose may generate more allies ....").

278. Id.

279. See Some Republican States Opting Out of High Risk Health Insurance Pools, supra note 208.

280. See Kliff \& Haberkorn, supra note 274 (noting that Minnesota and Alaska turned down federal assistance to set up an Exchange).

281. See Devins, supra note 44, at 134.

282. See David S. Hilzenrath, 18 States Decline to Run "High-Risk" Insurance Pools, WASH. Post, May 4, 2010, at A2 (noting that eighteen states have refused to set up their own high-risk insurance pools, leaving the job to the federal government, while twenty-nine states and the District of Columbia are taking on the job themselves).

283. See Kingsdale, supra note 239, at 2147 (noting that exchanges have become the "primary responsibility" of the states); Janet Adamy \& Laura Meckler, Support Grows for U.S. Health Exchange, WALL ST. J., Jan. 13, 2010, at A2 (describing the White House's push for national health insurance exchange); Peter Grier, Health Care Reform Bill 101: What's a Health "Exchange"?, CHRISTIAN SCI. MONITOR (Mar. 20, 2010, 2:35 PM), http://www.csmonitor.com/USA/Politics/ $2010 / 0320 /$ Health-care-reform-bill-101-What-s-a-health-exchange (noting national exchange bill "is gone with the wind"). 
It is also possible that states' vocal concerns about the costs and other burdens associated with establishing Exchanges will mount as the 2014 implementation date approaches. States' current focus on high-risk pools might be explained by the short, ninety-day time frame for compliance, with similar objections to state-based Exchanges yet to come. States may be engaged in strategic, if not opportunistic, federalism, staging challenges to ACA as each provision rolls out.

\section{Insurance Market Regulations}

States also have not objected to ACA's significant reallocation of power to regulate the health insurance market from the states to the federal government. Several provisions broadly preempt states' traditional authority over commercial health insurance companies operating in their borders. ${ }^{284}$ Some of the new federal health insurance regulations took effect almost immediately after ACA's enactment, beginning with the high-risk pools in June $2010 .{ }^{285}$ Within six months of the statute's enactment, insurers were required to allow dependent children to remain on their parents' policies until age $26 .{ }^{286}$ Effective January 1, 2010, ACA created mandatory, nationwide medical-loss ratios, meaning that large insurers are required to spend $85 \%$ of revenue on patient care and no more than $15 \%$ on non-medical, administrative expenditures. ${ }^{287}$ The medical-loss ratio for individual and small group policies is 80 to $20 .{ }^{288}$

More sweeping changes take effect on January 1, 2014. Insurers across the country will be prohibited from excluding individuals on the basis of pre-existing conditions, ${ }^{289}$ exceeding annual caps on patient cost-sharing, ${ }^{290}$ and rescinding coverage after individuals become ill. ${ }^{291}$ Guaranteed issue and renewability also take effect in $2014,{ }^{292}$ meaning that insurers will be required to accept everyone who applies for coverage and cannot refuse to renew policies based on health status, utilization of services, or other factors. All new individual and small-

284. See Jennings \& Hayes, supra note 32, at 2244-45 (noting that the ACA establishes new federal standards for insurance policies which all states must meet).

285. See, e.g., Patient Protection and Affordable Care Act, Pub. L. No. 111-148, § 1101 (a), 124 Stat. 119,141 (2010) (requiring the federal government to establish temporary high-risk pools within ninety days of the ACA's enactment).

286. Id. sec. 1001, $\S 2714(\mathrm{a}), 124$ Stat. at 132.

287. See id. sec. $10101, \S 2718(\mathrm{~b})(1)(\mathrm{A})(\mathrm{i}), 124$ Stat. at 886.

288. See id. sec. $10101, \S 2718(\mathrm{~b})(1)(\mathrm{A})(\mathrm{ii})$.

289. Id. sec. $1201, \S 2704(\mathrm{a}), 124$ Stat. at 154.

290. Id. sec. 1001, $\$ 2711$ (a)(2), 124 Stat. at 131.

291. Id. sec. $1001, \S 2712$.

292. Id. sec. $1201, \S \S 2702-03,124$ Stat. at 156. 
group health insurance policies offered through the Exchanges will be required to cover an essential benefits package ${ }^{293}$ and comply with one of four benefit categories (platinum, gold, silver, and bronze). ${ }^{294}$ Insurers will continue to be licensed and regulated by the states, ${ }^{295}$ but any state insurance laws will have to accord with the new federal laws. ${ }^{296}$

In 2014, insurers will also be restricted in plan pricing. The statute establishes nationwide modified community rating and specified rating bands. Insurers may not vary premium rates except based on age (limited to a three-to-one ratio), premium rating area, family composition, and tobacco use (limited to a 1.5-to-1 ratio) in the individual and smallgroup markets and the Exchanges. ${ }^{297}$ States are required to establish rating areas in compliance with the federal law. ${ }^{298}$ Waiting periods cannot exceed ninety days. ${ }^{299}$ The statute also limits beneficiary costsharing obligations. Deductibles in the individual and small-group markets are capped at $\$ 2000$ for individuals and $\$ 4000$ for families. ${ }^{300}$ In addition, new, standardized administrative and reporting requirements apply to all qualified plans.

ACA's new federal health insurance rules apply uniformly across the country with no state opt-out. As a matter of federal supremacy, states cannot adopt requirements that conflict with or impede the purpose of the federal law. ${ }^{301}$ Beginning on the effective date of each provision, any state law that does not meet the minimum federal standard will be preempted. States retain flexibility to adopt laws that provide greater protection to health insurance consumers, above the federal minimum, but cannot vary the requirements below that floor. ${ }^{302}$ Insurance market reforms in the federal legislation generally have received broad support from citizens and politicians. ${ }^{303}$ From a states'

293. See id. § 1302(a)-(b), 124 Stat. at 163-65.

294. See id. $\$ 1302(\mathrm{~d})(1), 124$ Stat. at 167.

295. Id. $\S 1301(\mathrm{a})(1)(\mathrm{C})(\mathrm{i}), 124$ Stat. at 162.

296. See Jennings \& Hayes, supra note 32 , at $2244-45$ (noting that the ACA sets minimum federal standards for insurers to meet).

297. Patient Protection and Affordable Care Act, sec. 1201, § 2701(a)(1)(A), 124 Stat. at 155.

298. Id. sec. 1201, § 2701(a)(2).

299. Id. sec. $1201, \S 2708,124$ Stat. at 161.

300. Id. $\S 1302(\mathrm{c})(2)(\mathrm{A}), 124$ Stat. at 166.

301. See McCulloch v. Maryland, 17 U.S. (4 Wheat.) 316, 436 (1819) ("States have no power ... to retard, impede, burden, or in any manner control, the operations of the constitutional laws ....").

302. See Patient Protection and Affordable Care Act § 1321(d), 124 Stat. at 187 ("Nothing in this title shall be construed to preempt any State law that does not prevent the application of the provisions of this title."); Jennings \& Hayes, supra note 32, at 2244 ("[The] ACA establishes new minimum federal standards for insurance policies ....").

303. See generally Kaiser family Found., Kaiser health Tracking POLl (2010), available at http://www.kff.org/kaiserpolls/upload/8042-F.pdf (tracking support for particular 
rights perspective, however, those new federal laws significantly intrude on states' authority and discretion to regulate private health insurers.

Insurance regulation was long considered within core state police powers to protect the health, safety, and welfare of their citizens. In 1945, Congress reaffirmed the states' authority to regulate insurance with the McCarran-Ferguson Act, ${ }^{304}$ which effectively reversed a U.S. Supreme Court opinion applying federal antitrust laws to the business of insurance. $^{305}$ The McCarran-Ferguson Act allows the federal government to regulate insurance only to the extent that states have not done so. ${ }^{306}$ Congress considered legislation to repeal the McCarranFerguson Act, ${ }^{307}$ but the repeal was not included in ACA. If the exemption were repealed, the federal government would gain substantial regulatory authority over insurers, further narrowing the space for state regulation.

In earlier legislation, Congress has exercised its preemptive powers over state regulation of health insurance. Most notably, the Employee Retirement Income Security Act of 1974 ("ERISA"), 308 enacted under federal commerce power, broadly preempts state laws that "relate to" employee benefit plans, including most employer health plans. ${ }^{309}$ ERISA also contains a generous savings clause that retains state authority over traditional insurance plans purchased by employers on behalf of their employees. $^{310}$ A separate ERISA provision preempts a host of state common law remedies for plan enrollees aggrieved or injured by health insurers' coverage decisions and administrative errors. ${ }^{311}$ ERISA is

provisions, including guaranteed issue); Doug Trapp, Health Reform Provisions Poll Well, Even if Bills Do Not, AM. MED. NEws (Mar. 22, 2010), http://www.ama-assn.org/amednews/2010/ 03/22/gvsb0322.htm ("More than three-quarters of Americans are in favor of reforming health insurance, including ending lifetime benefit limits and exclusions based on preexisting conditions ....').

304. 15 U.S.C. $\S \S 1011-15(2006)$

305. United States v. Se. Underwriters Ass'n, 322 U.S. 533, 553 (1944), superseded by statute, McCarran-Ferguson Act, 15 U.S.C. $\$ \S 1011-15$; Jost, supra note 77, at 55.

306. 15 U.S.C. $\$ 1012$ (b) ("No Act of Congress shall be construed to invalidate, impair, or supersede any law enacted by any State for the purpose of regulating the business of insurance ... unless such Act specifically relates to the business of insurance ....").

307. See Restoring American Financial Stability Act of 2010, S. 3217, 111 th Cong. (2010); Health Insurance Industry Fair Competition Act, H.R. 4626, 111 th Cong. (2010) (proposing an amendment to the McCarran-Ferguson Act); White House Supports Repeal of McCarran-Ferguson Act, ST. Louis U. J. HEALTH L. \& POL'Y (Feb. 24, 2010), http://lawblogs.slu.edu/2010/02/whitehouse-supports-repeal-of-mccarran-ferguson-act/.

308. 29 U.S.C. $\S \S 1001-1461$.

309. Id. $\S 1144(\mathrm{a})$.

310. See 29 U.S.C. $\S 1144(b)(2)(B) ; i d . \S 1132(b)$

311. See id. $\S 1132$ (a) (listing persons who may bring a civil action). 
widely considered a major obstacle to comprehensive state health reform. $^{312}$

The federal Health Insurance Portability and Accountability Act of 1996 ("HIPAA") 313 also preempts state law by establishing national standards for group health plans. HIPAA restricts insurers' use of preexisting condition exclusions for individuals who move between employer group plans or other "creditable" coverage. 314 The law also requires guaranteed issue for individuals with creditable coverage, ${ }^{315}$ although it does not limit the premium amounts that insurers may charge. State laws that do not meet the minimum federal requirements of HIPAA are preempted. ACA, in effect, extends HIPAA protections to the individual and small group market, and others with gaps in health insurance coverage or no prior "creditable" coverage.

ERISA and HIPAA notwithstanding, the federal government has largely refrained from substantively regulating the terms of health insurance plans or practices of health insurance companies, leaving those matters to state law. ${ }^{316}$ States have implemented various requirements on health insurance plans, including coverage mandates, affordability requirements, insurance mandates, ${ }^{317}$ marketing restrictions, and grievance and appeals rights. State laws focus particular regulatory attention on the small-group and individual markets, which tend to impose greater obstacles to coverage than the employer and large-group market. The number and specificity of the new ACA rules, especially those targeting the same markets that states currently regulate, represent a significant reallocation of authority from states to the federal government. With ACA, state policymaking discretion and, accordingly, insurance plan variability, is much more limited. But states generally have not expressed dissent over that loss of power, even to requirements that take effect almost immediately. Rather, states are actively preparing

312. See, e.g., Mary Anne Bobinski, Unhealthy Federalism: Barriers to Increasing Health Care Access for the Uninsured, 24 U.C. DAVIS L. REV. 255, 299 (1990); Peter D. Jacobson, The Role of ERISA Preemption in Health Reform: Opportunities and Limits, J.L. MED. \& ETHICS, Fall 2009 , at 88,88 ("Any comprehensive state-level health reform legislation or federal legislation that relies on state activity must take into account the states' vulnerability to ERISA preemption.").

313. Pub. L. No. 104-191, 110 Stat. 1936.

314. See 29 U.S.C. $\$ 1181$ (a)

315. See id. $\S 1182(\mathrm{a})$.

316. But see, e.g., id. $\S \S 1185(\mathrm{a})(1), 1185$ a(a) (listing very few federal coverage requirements under ERISA, including minimum hospital stays after childbirth and mental health parity).

317. See, e.g., Robert Steinbrook, Health Care Reform in Massachusetts-Expanding Coverage, Escalating Costs, 358 NEw ENG. J. MED. 2757, 2759 (2008) (discussing the health care reform in Massachusetts). 
for implementation by surveying existing legal authority and state resources to enforce the new federal standards. ${ }^{318}$

Squaring states' apparent tolerance for federal preemption of insurance regulation with the uncooperative federalism model turns on the scope of the preemptive effect. If federal preemption is read narrowly, then the insurance market reforms fit fairly well under the model. Uncooperative federalism encourages overlap and friction between spheres of state and federal authority as a means to foster productive dissent. ${ }^{319}$ With $\mathrm{ACA}$, the federal government reclaimed considerable insurance regulatory authority. If states are allowed space to adopt different policies and approaches, outside of the specific federal requirements, that tension may lead to useful, alternative approaches and testing of new laws. But if federal preemption of state regulation of health insurance is read broadly, states will be pushed to the margins with little room to object, silencing any productive dialogue. ${ }^{320}$ Until states begin to test the scope of their residual authority to regulate health insurance under ACA, it is difficult to fully consider the descriptive accuracy of the uncooperative federalism model.

There is, however, reason to doubt the model's predictions. Evidence can be drawn from states' reactions to existing federal insurance regulation under ERISA and HIPAA. ERISA has been interpreted to broadly preempt state regulation of employer health plans, including a wide swath of traditional common law tort and contract claims. This broad preemptive effect is considered to obstruct state health insurance reform and innovation. HIPAA, by contrast, does not expressly preempt state regulation or occupy the field but merely limits certain insurer practices for certain insureds, setting a federal floor. ${ }^{321}$ With respect to regulation of the individual insurance market, HIPAA expressly allows states to establish alternative mechanisms for extending access to insurance to individuals. All but ten states have established alternative programs, including pre-ACA high-risk insurance pools. ${ }^{322}$

318. See Pear, supra note 218 (noting that twenty states are prepared to run insurance pools under the ACA).

319. See Bulman-Pozen \& Gerken, supra note 43, at 1301-03.

320. See Emest A. Young, Two Cheers for Process Federalism, 46 VILL. L. REV. 1349, 1385 (2001) ("[Preemption] ensur[es] that states retain something meaningful to do ....").

321. See Karen Pollitz et al., Early Experience with "New Federalism" in Health Insurance Regulation, 19 HEALTH AFF. 7, 9 (2000), available at http://content.healthaffairs.org/content/19/4/ 7.full.pdf ("More protective state reforms (for example, shorter maximum preexisting condition exclusion periods) and state laws beyond HIPAA's scope (for example, rating rules) are not preempted if they do not prevent the application of HIPAA.").

322. See Kaiser Family Found., Non-Group Coverage Rules for HIPAA Eligible Individuals, 2010, STATE STATEHEALTHFACTS.ORG, http://www.statehealthfacts.org/comparetable.jsp?cat=7\& ind=356 (last visited Jan. 31,2010 ). 
HIPAA's relatively narrow preemptive effect was largely accepted without state objection. ${ }^{323}$ Thus, contrary to uncooperative federalism's doctrinal suggestion that narrow preemption will produce more friction and dialogue, whereas broad preemption will marginalize dissenting views, those examples suggest the opposite.

It is also possible that states will not object to the new federal insurance market reforms at all, despite the intrusion on traditional state sovereignty. Acknowledging their "two masters," ${ }^{324}$ states may find that the public favors those consumer-protective reforms, addressing some of the most notorious abuses of the commercial insurance industry. ${ }^{325}$ At the same time, states can pass the blame onto the federal government if insurance companies incorporated in their states or other interested constituents object to the new requirements. Uncooperative federalism values accountability, ${ }^{326}$ yet states may be strategically hiding behind the federal preemptive cloak to both silently support new laws popular with insureds and to avoid taking responsibility for laws objectionable to insurers. This analysis comports with opportunistic federalism: states raise federalism objections to advance certain objectives but accept federal control when other goals are paramount. ${ }^{327}$

\section{E. Individual Mandate}

The provision of ACA that has drawn the strongest, most persistent objection from states is the least intrusive on states' authority. Many states vehemently protest the mandate that every individual maintain health insurance. ${ }^{328}$ The individual mandate, however, requires nothing particular of states and will be implemented and administered entirely by federal authorities. ${ }^{329}$

Before and after ACA's passage, lawmakers in over forty states passed, introduced, or advocated state constitutional amendments or legislative resolutions, providing that individuals within the state shall not be required to participate in a particular health plan or prohibited from purchasing medical care directly from health care providers. ${ }^{330}$ The

323. See Pollitz et al., supra note 321, at 15-16 (describing delayed implementation in three states, Missouri, Rhode Island, and California, largely due to resource limitations).

324. Bulman-Pozen \& Gerken, supra note 43, at 1270

325. See SICKO (Dog Eat Dog Films 2007) (documenting the complaints about the U.S. health insurance industry).

326. See Bulman-Pozen \& Gerken, supra note 43, at 1289-91.

327. See supra notes 93-119 and accompanying text.

328. Patient Protection and Affordable Care Act, Pub. L. No. 111-148, § 1501(a), 124 Stat. $119,242-44$ (2010).

329. Id. sec. $1501, \S 5000 \mathrm{~A}(\mathrm{~g}), 124$ Stat. at 249.

330. See, e.g., Ariz. Sec'y of State, An Initiative Measure 1 (proposed Nov. 4, 2008), available 
nullification resolutions, modeled on the American Legislative Exchange Council's ("ALEC's") Freedom of Choice in Health Care Act, ${ }^{331}$ aim squarely at ACA's requirement to maintain individual health insurance. The current state proposals are ALEC's second-generation model laws. First-generation state nullification laws opposed a national health plan or mandatory public option, ${ }^{332}$ proposals which were never seriously considered with ACA.

Under ACA, beginning in 2013, U.S. citizens and legal residents must maintain minimum essential health insurance coverage. ${ }^{333}$ The individual mandate can be satisfied with coverage under Medicare, Medicaid, CHIP, veterans' health care programs, or the Peace Corps volunteers' health plan. ${ }^{334}$ Coverage under an eligible employersponsored plan, a plan offered in the individual market, or a grandfathered health plan will also suffice. ${ }^{335}$ Individuals will be required to report their coverage status on their annual federal income taxes, and failure to maintain coverage will result in monetary penalties. ${ }^{336}$ The penalty for the first year, 2014 , is a very modest $\$ 95 .{ }^{337}$ At full implementation, the penalty is $\$ 695$ per year, up to a maximum of three times that amount (\$2085), or $2.5 \%$ of household income, whichever is greater. ${ }^{338}$ The law provides exemptions based on religion, unlawful presence within the United States, incarceration, ${ }^{339}$ inability to afford coverage, ${ }^{340}$ hardship, membership in an Indian tribe, coverage for more than nine months of the year, ${ }^{341}$ and taxable income below the federal filing threshold. ${ }^{342}$

at http://www.azsos.gov/election/2008/info/pubpamphlet/english/Prop101.htm ("No law shall be passed that restricts a person's freedom of choice of private health care systems or private plans of any type[,]interferes[] with a person's or entity's right to pay directly for lawful medical services[,] nor impose a penalty or fine, of any type, for choosing to obtain or decline health care coverage or for participating in any particular health care system or plan.").

331. See Am. Legis. Exch. Council, ALEC's Freedom of Choice in Health Care Act: How Your State Can Protect Patients' Rights, ALEC, http:/www.alec.org/AM/Template.cfm?Section= ALEC_s_Freedom_of_Choice_in_Health_Care_Act 1 \&Template=/TaggedPage/TaggedPageDisplay .cfm\&TPLID=29\&ContentID $=13527$ (last visited Jan. 31, 2011).

332. See Jost, supra note 35 , at 869-70.

333. See Patient Protection and Affordable Care Act, sec. 1501, $\$ 5000 \mathrm{~A}(\mathrm{~g}), 124$ Stat. at 249.

334. Id. sec. $1501, \S 5000 \mathrm{~A}(\mathrm{f})(1)(\mathrm{A}), 124$ Stat. at 248

335. Id. sec. $1501, \S 5000 \mathrm{~A}(\mathrm{f})(1)(\mathrm{B})-(\mathrm{D}), 124$ Stat. at 248.

336. See id. sec. $1501, \S 5000 \mathrm{~A}(\mathrm{~b})(1)-(2), 124$ Stat. at 244.

337. See id. sec. $1501, \S 5000 \mathrm{~A}(\mathrm{c})(3)(\mathrm{B}), 124$ Stat. at 245.

338. See id. sec 1501, §5000A(c)(3)(D), 124 Stat. at 245, amended by Health Care and Reconciliation Act of 2010, Pub. L. No. 111-152, § 1002(a)(1)-(2), 124 Stat. 1029, 1032.

339. See Patient Protection and Affordable Care Act, sec. 1501, §5000A(d), 124 Stat at 246.

340. Id. sec. $1501, \S 5000 \mathrm{~A}(\mathrm{e})(1)(\mathrm{A}), 124$ Stat. at $246-47$.

341. Id. sec. $1501, \S 5000 \mathrm{~A}(\mathrm{e})(3), 124$ Stat. at 247.

342. Id. sec. $1501, \S 5000 \mathrm{~A}(\mathrm{e})(2), 124$ Stat. at 247. 
To assist individuals in complying with the mandate, ACA provides premium assistance federal tax credits for eligible taxpayers. ${ }^{343}$ Also, individuals with incomes above $100 \%$ but below $400 \%$ FPL are eligible for federal subsidies for beneficiary cost-sharing under certain plans purchased through the Exchanges. ${ }^{344}$ The federal government will inform insurers that an individual is eligible for cost-sharing reductions ${ }^{345}$ and then remit periodic and timely payments to the insurer to make up the premium difference. ${ }^{346}$

The policy goal of the individual health insurance mandate is to bring more people into the insurance market, including healthy individuals who often elect not to purchase health insurance, thereby spreading the risks more broadly and making insurance more affordable for all. ${ }^{347}$ Opponents invoke libertarian values and free market principles, objecting to a law that requires individuals to spend their own money on particular transactions or engage in particular conduct. ${ }^{348}$ The insurance mandate arguably intrudes on economic freedom to decline health insurance and personal autonomy rights to arrange and pay for medical care other than through third-party insurers, without government intrusion. More particularly, opponents of the individual mandate prefer a system in which each pays for his own medical costs, rather than effectively requiring healthy people to subsidize unhealthy people through insurance risk pools. ${ }^{349}$ In sum, the state nullification resolutions opposing the federal individual insurance mandate speak more in the language of individual than states' rights. ${ }^{350}$

343. Id. sec. $1401, \S 36 \mathrm{~B}(\mathrm{~b}), 124$ Stat. at 213-14.

344. Id. $\S 1402$ (b)(2), 124 Stat. at 221 (creating a sliding scale for incomes between $100 \%$ and $400 \%$ of the federal poverty level).

345. See id. $\$ 1402(\mathrm{a}), 124$ Stat. at 220-21

346. See id. $\S 1402(\mathrm{c})(3), 124$ Stat. at 222.

347. Id. $\$ 1501(\mathrm{a})(2)(\mathrm{G}), 124$ Stat. at 243 ("By significantly increasing health insurance coverage, the requirement, together with the other provisions of this Act, will minimize this adverse selection and broaden the health insurance risk pool to include healthy individuals, which will lower health insurance premiums.").

348. See Peter Urbanowicz \& Dennis G. SMITH, Constitutional Implications of AN "INDividual MaNdate" IN HEALTH CARE REFORM, THE FEderalist SOC'Y (2009), http://www.fed-soc.org/doclib/20090710_Individual_Mandates.pdf (noting that individual mandates may clash with the Fifth Amendment's Taking Clause).

349. See Michael F. Cannon, Cato Inst., All the President's Mandates: Compulsory HEALTH INSURANCE IS A GOVERNMENT TAKEOVER 1, 9-10 (2009).

350. See, e.g., Virginia Complaint, supra note 18, at 4-6 (arguing that individual mandate exceeds congressional power to regulate interstate commerce, operating as regulation of individuals' non-commercial conduct); Rivkin \& Casey, supra note 28; George F. Will, Unlawful Health Reform?, WASH. POST, Nov. 19, 2009, at A27 (noting arguments based on individual rights and personal autonomy). 
Because states have no particular role, servant or otherwise, to play in implementing or enforcing the mandate, it is difficult to place those objections within the uncooperative federalism model. ACA's individual mandate does not solicit state cooperation or commandeer state officials. The federal government does not depend on states to effect the mandate. $^{351}$ The individual mandate relies negligibly on state participation for implementation, imposing no additional burdens other than existing obligations to coordinate Medicaid eligibility, ${ }^{352}$ establish state-based Exchanges, ${ }^{353}$ and maintain existing state licensing and regulation of insurance companies offering qualified plans. ${ }^{354}$ Enforcement, exemptions, credits, and subsidies are tied to federal individual income tax rules, which are enforced and administered by federal authorities. ${ }^{355}$ Moreover, the individual mandate is novel. ${ }^{356}$ States, therefore, are not integrated or imbedded in an existing regulatory regime, which might give them a stronger voice in the policymaking conversation. $^{357}$

States' successful challenge to the individual mandate in the Florida lawsuit is not adequately explained as uncooperative federalism. Their winning theories were that the individual mandate exceeds congressional power to regulate interstate commerce ${ }^{358}$ and, furthermore, falls outside of the necessary and proper authority. ${ }^{359}$ Those are structural arguments about the proper scope of federal enumerated powers in relation to state reserved powers, not objections deriving from states' subservient posture with respect to federal policies.

Accordingly, opportunistic federalism offers a more plausible explanation for state resistance to the individual mandate, but it inaccurately characterizes state opposition. Opportunistic federalism posits that arguments about allocation of power are merely proxies for

351. See Bulman-Pozen \& Gerken, supra note 43, at 1266 ("States . . wield power against a federal government that depends on them to administer its programs.").

352. See supra notes $171-80$ and accompanying text.

353. See supra note 238 and accompanying text.

354. See Patient Protection and Affordable Care Act, Pub. L. No. 111-148, § 1301(a)(1)(C)(i), 124 Stat. 119, $162(2010)$.

355. See id. sec. $1501, \S 5000 \mathrm{~A}(\mathrm{f}), 124$ Stat. at $248-49$ (noting that the govemment will evaluate whether or not an individual has maintained minimum essential coverage pursuant to their tax return).

356. See Florida Summary Judgment, supra note 30 , at *71 (noting Congressional Research Service and Congressional Budget Office conclusions that the individual health insurance mandate is " "novel" and " unprecedented").

357. See id. at 1268-70 (discussing the theory of integration and observing that servants' power may also derive from integration).

358. See Florida Summary Judgment, supra note 30 , at *104.

359. See Florida Summary Judgment, supra note 30 , at *116. 
objections to substantive policies. ${ }^{360}$ It may well be that sponsors of state nullification amendments and resolutions would readily abandon their announced structural preferences if the individual insurance mandate were otherwise repealed. ${ }^{361}$ But even if repeal of ACA is the first-order priority, it is nevertheless significant that states' objections are grounded in the rhetoric of federalism. Indeed, structural federalism arguments carried the day in the Florida lawsuit. ${ }^{362}$

Initially, states opposing the individual mandate positioned themselves as advocates for their citizens' individual rights, consistent with the dual sovereignty ${ }^{363}$ and, especially, new federalism themes. ${ }^{364}$ The purported state interest is the discretion to recognize more liberal individual economic and personal autonomy rights for their citizens under states' reserved powers than the federal constitutional minimum. ${ }^{365}$ The Virginia lawsuit asserts state standing based on its particular sovereign interest in enforcing the recently enacted Virginia Health Care Freedom Act, against ACA's directly conflicting requirement. ${ }^{366}$ The Florida lawsuit asserted injury broadly to the states' sovereign interests as "protectors of the freedom, public health, and welfare of their citizens and residents. ${ }^{367}$ The Complaint alleged that the individual mandate is an unconstitutional tax that injures states' "exclusive authority, except to the extent permitted by the federal government by the Constitution, to make all taxing decisions affecting their citizens. ${ }^{368}$ Precisely striking a new federalism chord, the Plaintiff States claimed the exclusive authority, "to confer a right upon persons in their states to make health care decisions without government interference." $" 369$

Opportunistic federalism dismisses that new federalism posture as yet another disingenuous line of argument. ${ }^{370}$ But opportunistic federalism fails to explain why states, rather than individuals, led the

360. See supra notes 93-119 and accompanying text.

361. See Devins, supra note 44 , at 134 ("[T] manipulate federalism in order to secure preferred substantive policies is the rule.").

362. See Florida Summary Judgment, supra note 30, at *6-11 (framing decision in federalist rhetoric and principles).

363. See supra notes 53-66 and accompanying text (discussing the principle of dual sovereignty).

364. See supra notes 126-35 and accompanying text (discussing new federalism principles).

365. See Virginia Complaint, supra note 18, at 5-7; Florida Complaint, supra note 18, at 19.

366. See VA. CODE ANN. §38.2-3430.1:1 (Supp. 2010); Virginia Complaint, supra note 18, at $1-2,6$.

367. See Florida Complaint, supra note 18 , at 16.

368. Id at 17-18.

369. Id at 18 .

370. See Ryan, supra note 93 , at $600-01$. 
charge against the individual mandate. If opportunistic federalism is correct in suggesting that the public does not really care about or understand $^{371}$ the allocation of power between states and the federal government, ${ }^{372}$ it is hard to explain why state-oriented challenges have been at the center of the debate over the individual mandate. Libertarian, free market, individual rights arguments seem much more accessible and likely to resonate with the public. Moreover, individual citizens or public interest groups representing individuals have stronger standing to challenge the law. Judge Vinson's holding that the Plaintiff States had standing to pursue the constitutional challenge depended on the presence of two individual citizens, a small-business owner and an uninsured retiree, and two states, Utah and Idaho, which recently enacted state health reform nullification laws, among the group of plaintiffs. ${ }^{373}$ The persistence of state-based challenges to the individual mandate suggests that structural concerns are more meaningful to the public than opportunistic federalism acknowledges.

To summarize, state responses to ACA provisions can be mapped as follows:

Table 3

\begin{tabular}{|l|l|l|}
\hline STATES' ROLE & Power of the sovereign & Power of the servant \\
\hline Rivals/challengers & $\begin{array}{l}\text { 1. State autonomy; dual } \\
\text { sovereignty }\end{array}$ & $\begin{array}{l}\text { 2. Uncooperative } \\
\text { federalism }\end{array}$ \\
Individual Mandate & $\begin{array}{l}\text { Medicaid expansion } \\
\text { High-risk pools }\end{array}$ \\
\hline Allies/friends & 3. Functional theory & $\begin{array}{l}\text { 4. Cooperative federalism } \\
\text { Exchanges } \\
\text { Insurance market reforms }\end{array}$ \\
\hline
\end{tabular}

The provisions that have drawn the loudest objections and challenges from states include Medicaid expansion, high-risk pools, and the individual mandate. Medicaid expansion and high-risk pool objections fit within uncooperative federalism, Box 2 , to the extent that

371. See McGinnis \& Somin, supra note 97, at 90 ("Because of their rational ignorance of public policy, citizens will not consistently protect federalism, particularly because ... [it] lacks political salience ....").

372. See id. at 96 ("Federalism questions are unusually complex because they involve a wide range of policy areas and complicated intergovernmental relations .....").

373. See Florida Summary Judgment, supra note 30, at *34-37. 
the federal government is seeking to enlist states as servants. But uncooperative federalism is an inaccurate label because states seem powerless as servants to improve federal-state relations and policymaking. States' responses to the high-risk pools may fit the functional theory, Box 3 , as states seem to have freely bargained for use or denial of state administrative capacity to establish the pools. The individual mandate does not call for state cooperation or implementation and thus falls outside the "power of servant" column, fitting best under state autonomy or dual sovereignty, Box 1. For now, states are actively preparing to establish state-based Exchanges and have not objected to extensive new federal health insurance market reforms, placing those two provisions in cooperative federalism, Box 4 . In sum, state responses fall across the matrix and cannot be completely explained by uncooperative federalism.

Nor do states' reactions comport entirely with opportunistic federalism because states' appeals to structural federalism, in some cases, seem earnest. For example, states' objections to Medicaid expansion and high-risk pools invoke legitimate concerns about the budgetary and administrative burdens. Support for state-based Exchanges, the congressionally preferred approach, is consistent with state autonomy or dual sovereignty views. States' tolerance for federal preemption of state insurance regulation, however, does appear opportunistic inasmuch as that position compromises state autonomy in favor of politically popular consumer protection provisions. State-based dissent to the individual mandate resonates with new federalism themes, which may be earnest or opportunistic. My theory of rhetorical federalism encompasses the range of opportunistic and earnest invocations of federalism and offers the normative conclusion that both can be beneficial to the health reform conversation and federal-state relations. $^{374}$

\section{RHETORICAL FEDERALISM IN HEALTH CARE DECISIONMAKING}

The persistence and pervasiveness of state resistance to recent federal health reform legislation warrants attention. It is easy to dismiss the nullification movement as nothing more than Tea Party obstructionism and partisan politics designed to undermine the hardfought reforms. It is hard to take seriously state statutes and constitutional amendments proclaiming that federal laws do not operate within state borders. It is difficult to give much credence to states'

374. See supra Table 2 (placing rhetorical federalism in a two-by-two matrix). 
objections to federal commandeering under new Medicaid requirements when they otherwise willingly allow federal authorities to set up administrative shop inside their borders and broadly preempt state regulatory authority. State litigants raise novel constitutional challenges to the constitutionality of one of ACA's key provisions. ${ }^{375}$

Uncooperative federalism gives states too much credit for their various forms of dissent, while opportunistic federalism gives them too little credit for caring about the constitutional allocation of power. Bridging the two ideas, rhetorical federalism recognizes that even inconsistent, disingenuous invocation of federalism arguments may benefit both health care decisionmaking and federal-state relations. Like uncooperative federalism, rhetorical federalism finds value in states not simply falling in line with federal authorities. And like opportunistic federalism, rhetorical federalism acknowledges that federalism arguments have political salience aside from earnest concerns about the federal structure. Rhetorical federalism encompasses various principles, values, and slogans, and makes space for the discordant range of highly vocal to mild objections, as well as conspicuous non-objections. ${ }^{376}$ The health reform debate reveals a mix of deep concern for state autonomy and tolerance for central direction. ${ }^{377}$

This Article draws attention on the tendency of the current health reform conversation to stir up federalism values or sentiments. Rhetorical federalism, the theory that I offer to describe the current climate, is the highly public, highly vocal invocation of states' rights arguments to frame objections to comprehensive, sea-changing federal policies. I suggest that state-based resistance, whether motivated by earnest concerns about structural allocation of power or naked desire for political gain, can be valuable for a number of reasons.

First, rhetorical federalism brings transparency to the challenges of implementing a complex, multi-faceted package of reforms. Often, the general public, aside from motivated special interest groups, may be unaware and, therefore, not particularly involved with, the administrative rulemaking process and other implementation details behind federal legislation. ${ }^{378}$ Persistent state challenges reveal those

375. But see Florida Summary Judgment, supra note 30 , at $* 76$ (rejecting defendants' argument that the plaintiffs' Commerce Clause challenge should fail because the asserted distinction between "activity" and "inactivity" is "novel" and "unprecedented").

376. See Mark C. Gordon, Differing Paradigms, Similar Flaws: Constructing a New Approach to Federalism in Congress and the Court, 14 YALE L. \& POL'Y REV. 187, 204 (1996) ("[F]ederalism rhetoric ... justif[ies] often disparate and inconsistent approaches.").

377. See id. at 204 (characterizing President Ronald Reagan's approach).

378. See Karl S. Coplan, Ideological Plaintiffs, Administrative Law Making, Standing, and the Petition Clause, 61 ME. L. REV. 377, 393-94 (2009) ("[T]he agency legislative process is subject to 
mechanisms at work. ACA will gradually roll out over an elaborate timeline established in the statute. ${ }^{379}$ Because ACA heavily employs states as regulatory partners in implementing the comprehensive package of reforms, states will remain especially attuned to the law's impact. Each new call for state cooperation can be expected to give rise to another round of state resistance ${ }^{380}$ As the uncooperative federalism theory suggests, that ongoing tension between states and the central government may be part of a "well-functioning federal system.",381 Ongoing state dissent can increase public understanding of, or at least appreciation for, the challenges that lie ahead. The public will be regularly reminded of the law's price tag and asked to consider the government's ever-increasing role in health care delivery. Increased attention to the particulars of ACA implementation, particularly states' roles, can address accountability problems otherwise associated with cooperative federalism arrangements. ${ }^{382}$ Highly vocal, public statements by states, refusing federal requests for cooperation, helps to clarify lines of accountability, even if states ultimately agree to participate.

Rhetorical federalism also serves to educate the electorate on particular features of the comprehensive act by distilling it down to discrete issues. Post-enactment polling demonstrates that citizens' understanding of the details of ACA increased in the months that followed its passage. ${ }^{383}$ Polls also demonstrate that public support for discrete components of ACA is stronger than for the legislation as a whole. ${ }^{384}$ One interpretation of those data is that the law is simply too

influence by organized interest groups.").

379. See Kaiser Family Found., Implementation Timeline, HEALTH REFORM SOURCE, http://healthreform.kff.org/timeline.aspx (last visited Jan. 31, 2011).

380. See Hills, Federalism, supra note 52, at 193 ("[A]utonomous state and local politicians can be an insufferable thorn in Congress' side ...."); supra notes 275-80 and accompanying text (predicting that resistance to state Exchanges, similar to state high-risk pools, will arise as the implementation date approaches).

381. See Printz v. United States, 521 U.S. 898, 930 (1997) ("By forcing state governments to absorb the financial burden of implementing a federal regulatory program, Members of Congress can take credit for 'solving' problems without having to ask their constituents to pay for the solutions ... ."); New York v. United States, 505 U.S. 144, 168 (1992) ("[W]here the Federal Government compels States to regulate, the accountability of both state and federal officials is diminished."); Bulman-Pozen \& Gerken, supra note 43, at 1260, 1296.

382. See Bulman-Pozen \& Gerken, supra note 43, at 1289.

383. See KaISER Family Found., Kaiser Health TRaCKIng Poll 1 (2010) [hereinafter KAISER HEALTH TRACKING POLL], available at http://www.kff.org/kaiserpolls/upload/8075-F.pdf (showing decreased confusion from April to May 2010, two months after enactment); KAISER FAMILY FOUND., KAISER HEALTH TRACKING POLL (2010) [hereinafter KaISER SENIOR TRACKING POLL], available at http:/www.kff.org/kaiserpolls/upload/8082-F.pdf (tracking senior's awareness of health reform components).

384. See generally KAISER HEALTH TRACKING POLL, supra note 383, at 7 (tracking public reaction to specific proposals, compared to overall legislation). 
long and complex to be well understood, even by the elected representatives who enacted it, much less the general public. But recent studies show a growing understanding of the new law. ${ }^{385}$ Ongoing, postenactment state resistance to each provision of ACA that rolls out should continue to inform the public about the new law in more digestible bites.

States' very active role in the health reform debate is also valuable in giving voice to minority views that may not be heard in national debates. Our system of representative government envisions that individual constituents will share their concerns and objections with locally elected senators and representatives, who then carry those views into the federal forum. ${ }^{386}$ But when Congress and the White House are in the same party control, dissenting views may not be heard outside of state-level politics. ${ }^{387}$ Accordingly, states serve as the "fourth branch" of government. ${ }^{388}$ Even if Washington's political power is more evenly divided, state governments allow alternative fora for citizen participation in the political process. State legislatures may be more accessible and responsive to constituents' concerns than Congress. ${ }^{389}$ Local representatives also may embrace particular values and priorities of their communities, which may not be shared by the entire nation. ${ }^{390}$ Different territories may have different tastes and needs, especially on social

385. See id.

386. See Garcia v. San Antonio Metro. Transit Auth., 469 U.S. 528, 554 (1985) (noting that, although there has been changes in the federal-state relationship since the inception of the nation, the fundamental relationship between the federal government and the state government still exists); Jesse H. Choper, Judicial Review and the National Political Process: a Functional RECONSIDERATION OF THE ROLE OF THE SUPREME COURT 176-81 (1980); Larry D. Kramer, Putting the Politics Back into the Safeguards of Federalism, 100 COLUM. L. REV. 215, 279 (2000).

387. See Young, supra note 37 , at 1286 (" $[\mathrm{T}]$ he party that is 'out' in Washington will almost certainly be 'in' in at least a couple of dozen states and literally thousands of localities ....").

388. See Bulman-Pozen \& Gerken, supra note 43, at 1285; Hills, Federalism, supra note 52, at 182 ("In effect, state and local governments serve as a kind of "fourth branch' of the federal government, even more so than so-called independent federal regulatory agencies.").

389. See Garcia, 469 U.S. at 575 n.18 (Powell, J., dissenting) ("The Framers recognized that the most effective democracy occurs at local levels of government, where people with firsthand knowledge of local problems have more ready access to public officials ...."); Amar, Five Views, supra note 55, at 1234 ("[F]ederalism operates to edify and engage the citizenry."); Chemerinsky, supra note 56, at 527 ("[A] frequently invoked value of federalism is that states are closer to the people and thus more likely to be responsible to public needs and concerns."); Grey, supra note 56, at 511 (noting that federalism values local politicians as they are more responsive than Congress to the concerns of the citizenry).

390. See Shirley S. Abrahamson, Reincarnation of State Courts, 36 Sw. L.J. 951, 965-66 (1983) (suggesting that state constitutional interpretation should consider the state's "peculiarities"); Peter D. Jacobson, The Federalist Approach to Health Care and Its Limitations: Introductory Remarks, 29 HAMLINE J. PUB. L. \& POL'Y, at v, xii (2007) ("The individual states are closer to the people, and hence better equipped to reflect their plurality of values."); Schapiro, supra note 129, at 403 (discussing the position that state constitutional interpretation should rely on distinctive attributes of the state). 
policy matters. ${ }^{391}$ The diversity of approaches creates a political marketplace, allowing citizenry a choice rather than a one-size-fits-all approach to policymaking. ${ }^{392}$

Not only do states represent the diverse preferences of their citizens, but also state representatives may be in a better position to make those preferences known. Framing objections to substantive polices in terms of states' rights, even when state interests seemingly are not implicated, vocalizes constituents' views on the merits of the new federal law. State officials, including members of Congress, state legislators, attorneys general, and insurance commissioners, are more politically connected and may have stronger voices in the national dialogue than any individual voter. ${ }^{393}$ One of the values identified with uncooperative federalism is the ability of states to express dissenting views of their constituents from a more advantageous, insider status. ${ }^{394}$ At the same time, state politicians garner support from voters who oppose the law, consistent with opportunistic federalism's observations, ${ }^{395}$ uncooperative federalism's two masters notion, ${ }^{396}$ and the federalist design itself. ${ }^{397}$

Another value of thetorical federalism is codifying dissent, my original working thesis, when I predicted modest, if any reforms, would pass. ${ }^{398}$ Although sweeping legislation was enacted, there is movement afoot to repeal particular provisions or the entire ACA statute. ${ }^{399}$ With many of ACA's key provisions not taking effect for several years ${ }^{400}$ and

391. See Weil \& Tallon, supra note 57 , at 690 ("[S]tate policies can be more closely tailored to local economic conditions and can reflect local values ....").

392. See Amar, Five Views, supra note 55, at 1236-37; Young, supra note 58, at 54 ("[T]he best way to please more of the people more of the time is to offer a choice of regulatory regimes.").

393. See Bulman-Pozen \& Gerken, supra note 43, at 1268-70; Young, supra note 37, at 1285 ("Individuals are often ineffective speakers when they act alone.... [O]ften the most effective organizations for organizing and transmitting dissent are themselves governmental institutions.").

394. See Bulman-Pozen \& Gerken, supra note 43, at 1288-89.

395. See supra notes 101-08 and accompanying text (discussing McGinnis and Somin's thesis).

396. See Bulman-Pozen \& Gerken, supra note 43, at 1270-71.

397. See Young, supra note 37, at 1285-86 (suggesting that it was the Founders' intention that state and local politicians would convey the dissenting opinions of their constituents).

398. See supra note 3 and accompanying text.

399. See REPUBliCANS IN CONG., A PLEDGE TO AMERICA 25-28 (2010), available at http://pledge.gop.gov/resources/library/documents/solutions/a-pledge-to-america.pdf; Robert Lowes, House Votes to Repeal Healthcare Reform Law, MEDSCAPE MED. NEwS (Jan. 19, 2011), http://www.medscape.com/viewarticle/735967; Felicia Sonmez, Senate Defeats Republican-Led Health-Care Repeal Effort, WASH. POST, Feb. 2, 2011, http://voices.washingtonpost.com/44/2011/ 02/senate-debates-health-care-rep.html.

400. See Kaiser Family Found., supra note 379 (noting that several of the ACA's provisions will not go into effect for several years); Mark Murray, NBC/WSJ Poll: GOP Poised for Big Midterm Gains, MSNBC.COM (Oct. 20, 2010, 8:04 AM), http://www.msnbc.msn.com/id/39748015/ 
midterm elections bringing a shift in congressional power, ${ }^{401}$ the legislation remains vulnerable. State nullification laws, even if legally null as a matter of federal supremacy, ${ }^{402}$ serve to codify dissent and avoid the "Groundhog Day" repetition of failed proposals that tend to bog down health reform debates. ${ }^{403}$ State constitutional amendments and legislative resolutions may capture the popular opinion that particular approaches, whether universal health care, a public option, or an individual mandate, will be political non-starters. Perhaps then the debate can move past those proposals toward more likely consensus.

Health reform nullification amendments and resolutions, even if legally unenforceable, may serve a valuable expressive function by codifying state values and opinions. The laws are similar to state constitutional provisions that proclaim health as a fundamental right or public concern, ${ }^{404}$ anti-abortion trigger laws, ${ }^{405}$ or constitutional "directive principles." 406 Those laws do not give rise to individually

ns/politics-decision_2010\%.

401. See Peter Baker \& Carl Hulse, Deep Rifts Divide Obama and Republicans, N.Y. TIMES, Nov. 4, 2010, at Al (reporting that Republicans gained control in the House and describing the midterm elections as "the biggest swing since the 1948 election under Harry S. Truman").

402. See Jost, supra note 35, at 869 (evaluating the legality of state nullification laws).

403. See David A. Hyman, The Massachusetts Health Plan: The Good, the Bad, and the Ugly, 55 U. KAN. L. REV. 1103, 1117 (2007) ("In Groundhog Day, Bill Murray is forced to live the same day over and over again. The debate over the uninsured has had a similar feel for the past several decades." (footnote omitted)); see also Victor R. Fuchs, Health Care Reform-Why So Much Talk and So Little Action?, 360 NEW ENG. J. MED. 208, 208 (2009) ("[S]everal previous presidents have attempted to enact some kind of national health insurance: Harry Truman in the 1940s, Richard Nixon in the 1970s, and most recently Bill Clinton in the 1990s. These attempts went nowhere."); Jonathan Oberlander, Great Expectations-The Obama Administration and Health Care Reform, 360 NEW ENG. J. MED. 321, 322 (2009) ("Obama's health plan (as outlined during the campaign) clearly embodies additional lessons from the Clinton reform debacle ....").

404. See Elizabeth Weeks Leonard, State Constitutionalism and the Right to Health Care, 12 U. PA. J. CONST. L. 1325, 1348, 1350, 1359 (2010) (discussing state laws which cite health as a public concern).

405. See William Michael Treanor \& Gene B. Sperling, Prospective Overruling and the Revival of "Unconstitutional" Statutes, 93 COLUM. L. REV. 1902, 1918-20 (1993); Matthew Berns, Note, Trigger Laws, 97 GEO. L.J. 1639, 1640-42 (2009) (explaining that trigger laws are presently unconstitutional substantive provisions that are designed to come into effect if there is a change in constitutional law that would make the provision enforceable).

406. See, e.g., INDIA CONST. art. 37 ("The provisions contained in this Part [IV] shall not be enforceable by any court, but the principles therein laid down are nevertheless fundamental in the governance of the country and it shall be the duty of the State to apply these principles in making laws."); IR. CONST., 2004, art. 45 ("The principles of social policy . . . are intended for the general guidance of the Oireachtas. The application of those principles ... shall not be cognizable by any Court under any of the provisions of this Constitution."); CONSTITUTION OF NIGERIA (1999), §§ 1324 (listing the fundamental objectives and directive principles of state policy); see also Althouse, supra note 38, at 1254-55 (discussing a municipal resolution asserting its own constitutional commentary); Gary Jeffrey Jacobsohn, The Permeability of Constitutional Borders, 82 TEX. L. REV. 1763,1770 (2004) (describing India and Ireland's directive principles). 
enforceable rights but operate as conspicuous expressions of preferences or guiding principles. Similarly, state laws purporting to nullify the federal individual insurance mandate may be understood as expressions of broad public sentiment that health is a matter of individual, not government, responsibility. ${ }^{407}$ Even if laws such as Virginia's ${ }^{408}$ are deemed legally null and preempted by ACA, they nevertheless have rhetorical value in memorializing citizens' preferences.

Another value of rhetorical federalism may be repackaging the health reform debate in politically neutral language, thereby depoliticizing highly charged issues and overcoming voter fatigue. Objections based on the Tenth Amendment or state autonomy grounds suggest no partisan preference or view on the underlying substantive policies. By framing objections to ACA as concern for the allocation of power within the federal system, dissenters may more effectively capture the public's attention. Congressional and public debates over ACA were long, bitter, and highly charged. Even if opportunistic federalism is accurate in suggesting that opponents do not particularly care about structure of government, federalism slogans provide seemingly neutral grounds for objecting to controversial political issues, such as health care rights and the role of government in health care decisionmaking. In addition, ACA opponents may gain credibility by rising above the fray, objecting on seemingly principled, even patriotic, ${ }^{409}$ rather than political, grounds. Federalism rhetoric is beneficial in recapturing the public's attention and keeping it engaged in the ongoing consideration of fundamental values and policies.

Finally, rhetorical federalism highlights the increased government involvement in health care delivery, renewing deliberation about the appropriate role of states in federal policymaking and government in individuals' lives. Federalism slogans enliven the ongoing debate over deep ideological and constitutional issues regarding personal autonomy, government responsibility, and health care rights. Even when opponents adopt inconsistent positions, the health reform nullification movement, for all its distractions, persistently impresses those issues on the electorate. "There is no need for a single coherent problematic to dominate; a movement might successfully force a conflicting set of

407. See, e.g., Young, supra note 37, at 1298-99 (arguing that a state law, that would be preempted by federal law, can be a form of political expression).

408. See VA. CODE ANN. § 38.2-3430.1:1 (Supp. 2010).

409. See Edward L. Rubin \& Malcolm Feeley, Federalism: Some Notes on a National Neurosis, 41 UCLA L. REV. 903, 906 (1994) ("We Americans love federalism . . . It conjures up images of Fourth of July parades down Main Street, drugstore soda fountains, and family farms with tire swings in the front yard."). 
issues onto the center of the nation's political consciousness." 410 The state nullification movement demands that we consider, and reconsider, our deeply held views on rights and responsibility, the role of government, and state identity.

\section{CONCLUSION}

This Article considers the rhetorical value of federalism in health care decisionmaking. We are in the very early stages of ACA implementation; thus, any assessment of the impact of the ongoing nullification movement is necessarily predictive. With that caveat in mind, this Article offers a novel affirmative take on the seemingly distracting and destructive trend of state resistance to federal health reform. My notion of rhetorical federalism draws on previously articulated federalism theories, recognizing, like uncooperative federalism, that dissent can be productive, and, like opportunistic federalism, that state objections may be pretextual. Federalism values are not easily defined and are the subject of widely varying opinions. Likewise, sweeping health reform legislation like ACA relies on an array of approaches and strategies, each particular provision of which invites different reactions. The debate over health reform, not surprisingly, places issues of individual rights and the role of government in health care at the center of politics. The national conversation also has the perhaps unexpected effect of placing the ancillary issue of allocation of power between the central government and the sovereign states squarely before the electorate.

410. Ackerman, supra note 138 , at 1519 . 